\title{
Financial Inclusion and Development in the CEMAC
}




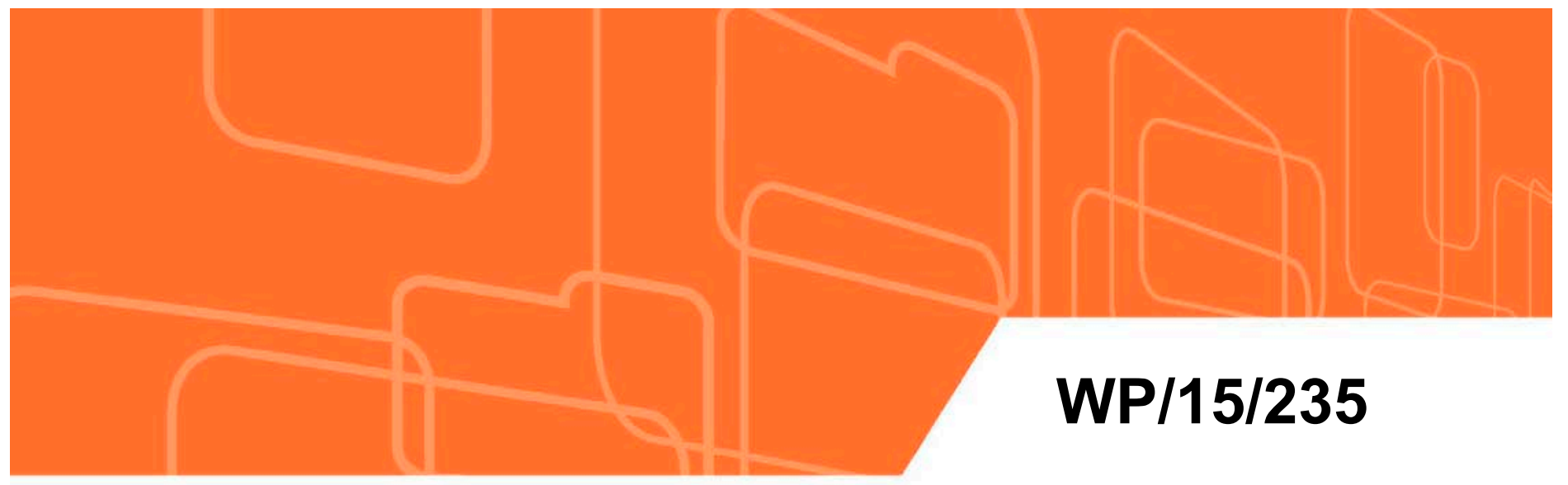

\section{IMF Working Paper}

\section{Financial Inclusion and Development}

\section{in the CEMAC}

by Adrian Alter and Boriana Yontcheva

IMF Working Papers describe research in progress by the author(s) and are published to elicit comments and to encourage debate. The views expressed in IMF Working Papers are those of the author(s) and do not necessarily represent the views of the IMF, its Executive Board, or IMF management.

$$
\text { I N T E R N A T I O N A L M O N E T A R Y F U N D }
$$




\title{
IMF Working Paper
}

\author{
African Department
}

\section{Financial Inclusion and Development in the CEMAC ${ }^{1}$ \\ Prepared by Adrian Alter and Boriana Yontcheva}

Authorized for distribution by Mario de Zamaroczy

November 2015

\section{IMF Working Papers describe research in progress by the author(s) and are published to elicit comments and to encourage debate. The views expressed in IMF Working Papers are those of the author(s) and do not necessarily represent the views of the IMF, its Executive Board, or IMF management.}

\begin{abstract}
This paper examines financial inclusion and development in the CEMAC. We explore the level of financial inclusion in the CEMAC through a benchmarking exercise. We construct a measure of financial development gap and analyze its determinants. Using panel data regressions, we find that inflation, income, and natural resources explain most of the financial development level but that better financial sector governance and stronger economic governance are positively associated with financial sector development. Richer and poorer countries can be equally far from their expected financial development levels. Finally, we use a benchmarking exercise to identify countries that have successfully reduced the financial development gap and propose policy measures that CEMAC countries could use to boost financial inclusion.
\end{abstract}

\section{JEL Classification Numbers: G18; G21}

Keywords: financial inclusion; financial development gap; benchmarking; poverty

Author's E-Mail Address: aalter@imf.org ; byontcheva@imf.org

\footnotetext{
${ }^{1}$ We are very thankful for comments from Karim Barhoumi, Jorge Canales, Domenico Fanizza, Mario de Zamaroczy, Dalia Hakura, Manos Kitsios, Bernard Laurens, Montfort Mlachila, Camelia Minoiu, Galen Sher, Raju Singh and participants at an IMF seminar. All remaining errors are our own.
} 


\section{Contents}

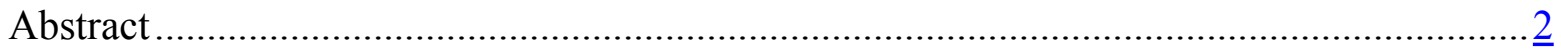

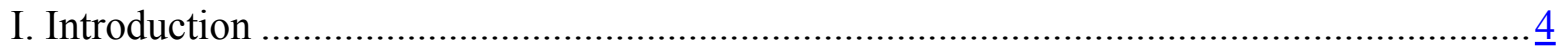

II. Financial Development in SSA and the CEMAC ……..............................................

A. Literature review

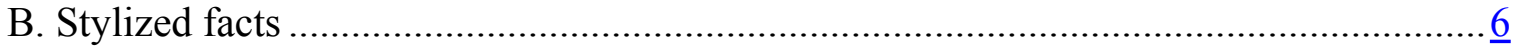

III. The Determinants of Financial Inclusion and development in the CEMAC .................... 10

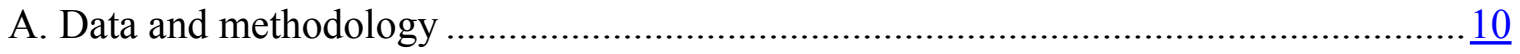

Dependent variables .................................................................................... 10

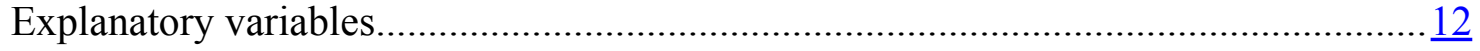

B. Empirical Model.......................................................................................

C. Results: The determinants of financial development .................................................. 15

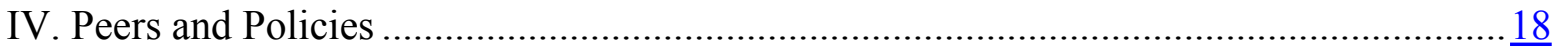

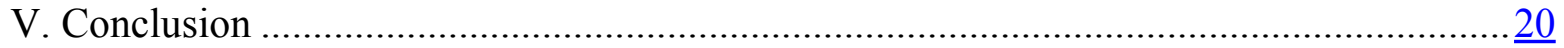

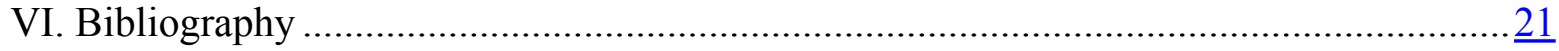

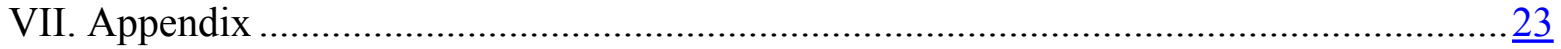

VIII. Technical appendix: Benchmarking financial development ......................................... 31 


\section{INTRODUCTION}

Financial development in Sub-Saharan Africa (SSA) is uneven and on average less advanced than in other low-income regions, despite recent progress and reforms. ${ }^{2}$ Within SSA, the Central African Economic and Monetary Community (CEMAC) region lags further behind. ${ }^{34}$ As the literature has extensively illustrated, financial development impacts economic growth and can play a critical role in reducing poverty and inequality. The importance of fostering the financial sector and promoting access to financial services is thus vital to development efforts for the CEMAC.

The contribution of this paper is twofold. First we examine the level of financial development in the CEMAC comparing it with peers from SSA and identify where the region stands once structural characteristics have been accounted for. We show that all CEMAC countries have a less developed and less inclusive financial sector relative to their peers and relative to their expected development given their structural characteristics. These results support those of Singh et al. (2009); while they found that Zone Franc countries had more shallow financial sectors, we show they are also less inclusive. Second, we then turn to factors that could cause this relative underdevelopment. We widen our sample to all SSA countries, construct a "financial development gap" measured as the gap between the actual level of development of the sample countries and their expected development level or "benchmark" and adopt an explanatory model based on macroeconomic factors, institutional variables, and banking sector characteristics. The identification of our CEMAC countries is linked to their membership of the currency union, the CFA franc. Our results confirm that countries with higher income levels tend to have more developed financial sectors and that inflation adversely affects financial sector development. However, we also find that better credit information and rule of law is positively associated with financial sector development and higher cost ratios are negatively related to financial sector development. Better general economic governance is positively associated with financial sector development in CEMAC countries. Finally as our evidence suggests that there is scope for policy to boost financial development, we identify "best performers" in Africa and focus on policy measures that help to boost financial inclusion.

Our paper is also related to the financial benchmarking literature. Using cross-country financial data, Beck, et al. (2008) propose a methodology to benchmark the policy component of financial development. Čihák, et al. (2012) introduce the Global Financial Development Database (GFDD) which documents characteristics of the financial sector from over 200 countries. In this paper we use their benchmarking approach both to assess financial development in the CEMAC and to construct a measure of financial development "gap" for countries in our entire sample.

\footnotetext{
2 The World Bank's 2014 Global Financial Development Report finds that half of the world's population is unbanked, while this ratio is about 75 percent in SSA.

${ }^{3}$ In this study we consider two dimensions of financial development: financial inclusion defined by access to financial services and financial depth which measures the extent to which banks finance economic activity.

${ }^{4}$ The Central African Economic and Monetary Union or CEMAC includes Chad, Congo, Central African Republic, Cameroon, Gabon and Equatorial Guinea.
} 
The rest of this paper is organized as follows. Section II reviews the literature and presents stylized facts regarding financial inclusion and development in the CEMAC relative to peer countries. Section III turns to the determinants of financial development and discusses the data, methodology and presents empirical results. Section IV presents policy recommendations derived from identified "successful" reformers and section V concludes

\section{Financial DeVElopMent In SSA AND THE CEMAC}

\section{A. Literature review}

Before moving forward with our analysis, we review the theoretical background that presents why financial development is important for economic growth and poverty reduction. Moreover, we discuss a set of factors which are potentially tied to the development of financial services. These factors will then help us build our model and explain financial development in our sample.

The importance of financial development for economic growth has been extensively documented in the past two decades. King and Levine (1993) and Rajan and Zingales (1998) argue that financial development can predict long-term economic growth, capital accumulation and productivity growth. In addition, Burgess and Pande (2005) and Levine (2005) have shown that the relationship between financial development and long-term economic growth holds sway for developing economies as well as advanced ones.

Theoretical models that consider the interaction between growth and financial development emphasize several channels and mechanisms (e.g. Levine (2005) and Murinde (2012)): (i) endogenous models in which financial institutions direct savings more efficiently to productive investments and enhance growth; (ii) models that focus on the capital allocation channel and in which financial markets, institutions, and instruments may address the effects of information asymmetries and reduce the transaction costs of potential investment opportunities; (iii) models that include the external sector, and in which financial institutions play the role of channeling the financial inflows towards domestic activities; and (iv) a new generation of theoretical models that capture the nexus between financial constraints, economic growth, wealth inequality, and poverty (e.g. Dabla Norris, et al. (2014), IMF (2015)). Beck, et al. (2007) show that financial development can alleviate poverty as the poor benefit enormously from basic payments, savings, and insurance services that can help smooth shocks.

Financial sector development is commonly explained by macroeconomic factors, structural factors (loosely defined as factors that cannot be changed rapidly) and policy-sensitive factors. Among the first set, the overall level of economic development measured by income per capita will be positively correlated with higher financial development as richer countries have more savings and greater demand for financial services. Inflation negatively impacts financial service as it aggravates asymmetries of information and reduces the return on lending (Boyd, et al. (2001)). Structural country characteristics that have been studied are population size and density, and age dependency ratio. Countries with larger populations and higher population densities are expected to have more developed financial services due to economies of scale in the costs of financial intermediation. The share of urban versus 
rural population is likely to capture the cost of providing financial services and affect the development of the financial sector. Finally, policy-sensitive factors like contract enforcement and property rights are found to be positively associated with financial development (see e.g., Detragiache, et al. (2005)). Moreover, credit infrastructure and market liberalization may contribute positively to financial development (see e.g., Demetriades and Fielding (2011), Ahokpossi, et al. (2013)).

\section{B. Stylized facts}

We look at two dimensions of financial development, namely access to finance and financial depth. Access to finance is proxied by the number of bank branches per inhabitant and financial depth is measured by the ratio of private credit to GDP. The former is typically identified as a measure of access to banking services and financial inclusion and the latter a measure of financial depth and the extent to which banks finance the economy. Although typically access and depth measures have different focuses and some countries could have deep financial sectors with little inclusion, both access and depth measures are highly correlated in our sample countries. ${ }^{5}$

Figure 1 presents some cross-country comparisons. In most SSA countries, private sector credit has grown rapidly since the mid-2000s but the financial sectors remain shallow when compared to other low-income countries globally. As shown in Figure 1.1, the average private credit-to-GDP ratio across 42 countries in SSA jumped to 22 percent in 2012, but the same ratio is much higher in other developing countries worldwide. Within SSA, the financial sectors in the CEMAC are even shallower than in the rest of the continent (Figure 1.2). Turning to inclusion, access to financial services is also very uneven within SSA and particularly low in the CEMAC. (Figure 1.3 and 1.4) The share of adults with formal savings is on average around 7.5 percent in the CEMAC. Even before the current conflict situation, formal savings in Central African Republic were the lowest in the region while Cameroon ranks highest. The most important constraint cited by adults for not having a formal bank account is "lack of money", possibly reflecting high deposit requirements compared to income (according to Findex database, 2012). However, service costs and distance to the closest bank branch are also commonly cited factors. Bank services (e.g. opening and maintenance of a bank account) in the CEMAC are costlier compared with other banks in the region.

In addition, access to formal savings and loans is particularly restricted for the poor and for women. Both groups have less access in all regions but the discrepancy is stronger in the CEMAC. In the CEMAC, 23 percent of the "better off" population has a formal account compared with only 4 percent among the "worse off" and women in the CEMAC have a lower access to financial services than men compared to their peers in SSA. Only 6.8 percent of women have a formal financial account compared to 11.3 percent of the male population. The ratio of men to women with formal accounts is therefore around 1.66 which

\footnotetext{
${ }^{5}$ Given data constraints, mobile banking and microfinance institutions were not included in the measure of financial services
} 
is much higher than in frontier and emerging SSA economies where available data show that this ratio is only $1.22 .{ }^{6}$

While Figure 1 illustrates some stark differences and highlights the diversity of financial sector development in Africa, simple cross-country comparison can be misleading as financial sector development is strongly linked to income levels and other characteristics of compared countries. It is more meaningful to assess financial sectors while controlling for the level of economic development and other structural, country-specific factors. This can be done through a benchmarking exercise: by taking into account the most important nonpolicy factors affecting financial sector development while excluding all policy-driven factors, the statistical benchmark determines the expected level of financial sector development in a policy-neutral environment. Deviations with respect to the benchmark can therefore be attributed to the country's policies.

For each country, we use the World Bank's FinStats database based on initial methodology developed in Beck, et al. (2008) to retrieve the financial indicator benchmarks which are based on the country's economic and structural characteristics. Each financial indicator is regressed on a set of structural characteristics, such as GDP per capita and its square (to account for potential non-linearities linking economic and financial development, see e.g. Arcand, et al. (2012)), population size and density, the age dependency ratio, countryspecific dummies and year fixed effects. Regressors also include a dummy for natural resource exporters, as worldwide evidence shows that resource rich countries tend to have comparatively smaller financial sectors than other countries at similar levels of income, reflecting the fact that oil revenues can boost GDP out of proportion with the country's overall level of economic and financial development. Therefore, given the structural characteristic of the country, regressions provide an expected benchmark level of financial development that the country could achieve. ${ }^{7}$

By defining and analyzing the financial development gap as the ratio between the actual and the expected benchmark of a financial indicator, we aim to understand what explains the difference between the actual development level of financial sectors in SSA countries and their expected level given their development level and structural characteristics.

As can be seen in Figure 2, selected countries in the CEMAC underperform their expected benchmarks in both financial depth and financial inclusiveness. ${ }^{8}$ Access to financial services in the CEMAC is not only limited, but it is falling behind other regions in Sub-Saharan Africa and other peers. ${ }^{9}$ Cameroon's indicators track those of their peers closely, while Gabon, one of the countries with the highest income per capita in the region, underperforms

\footnotetext{
${ }^{6}$ The group of SSA frontier and emerging economies refers to the following countries: Ghana, Kenya, Mauritius, Nigeria, Senegal, South Africa, Tanzania, Uganda, and Zambia.

${ }^{7}$ A detailed description of the methodology is provided in the Technical Appendix.

${ }^{8}$ Similar developments and trends are observed for the rest of the region. (Figure 7, Appendix)

${ }^{9}$ The detailed indicators of financial inclusion for the entire SSA are presented in Table 8, Appendix.
} 
its benchmarks of financial access and depth, as proxied by the number of bank branches and private credit to GDP. ${ }^{10}$

Figure 1. Selected financial development and inclusion indicators in sub-Saharan Africa and CEMAC

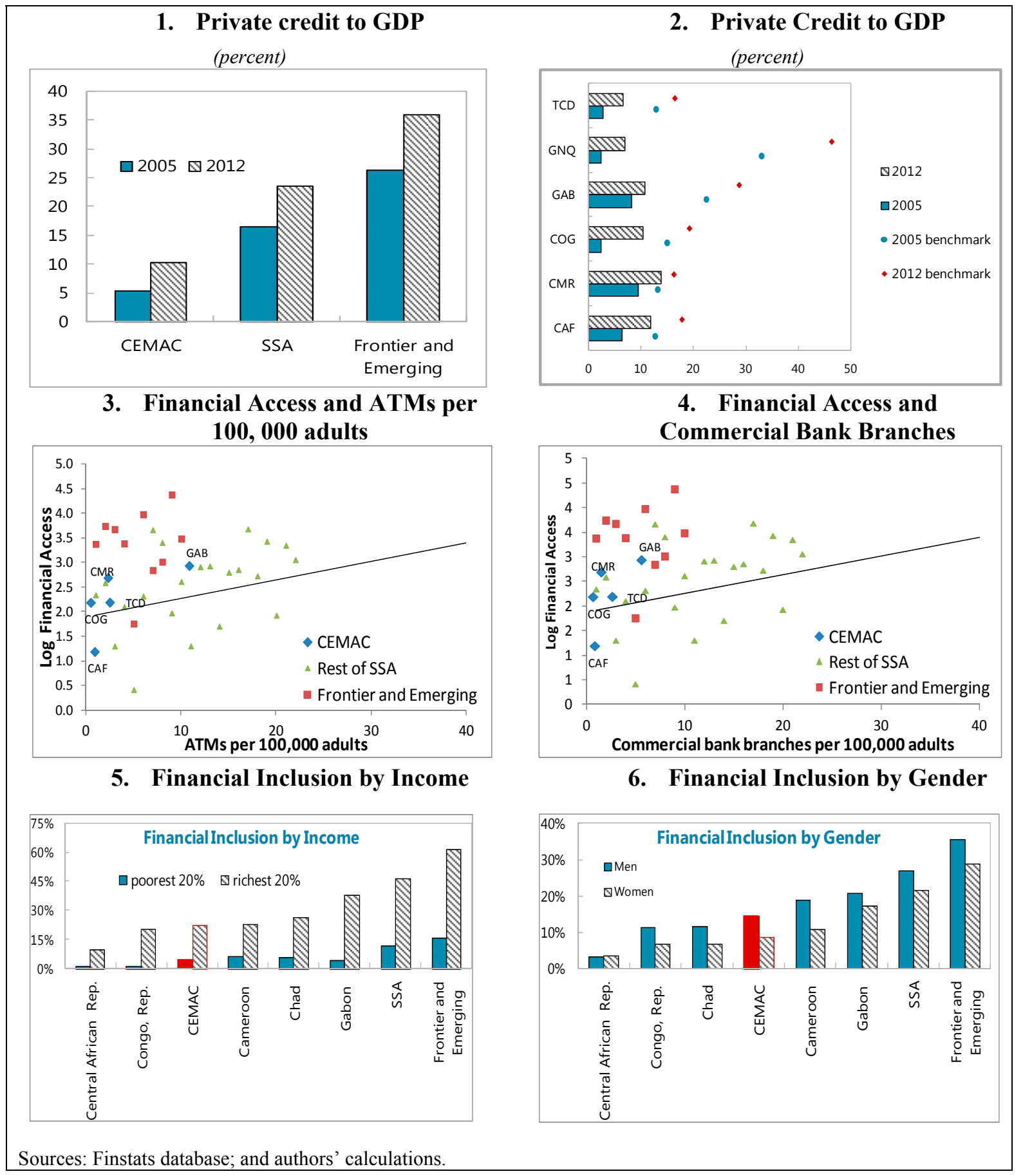

\footnotetext{
${ }^{10}$ The selected indicators only measure the formal banking sector and microfinance institutions are not taken into account. In Congo and Cameroon, they are help service the unbanked but their share of the financial sector remains below 5 percent of total assets.
} 
Figure 2. Benchmarking financial development in selected CEMAC countries (2004-2012)

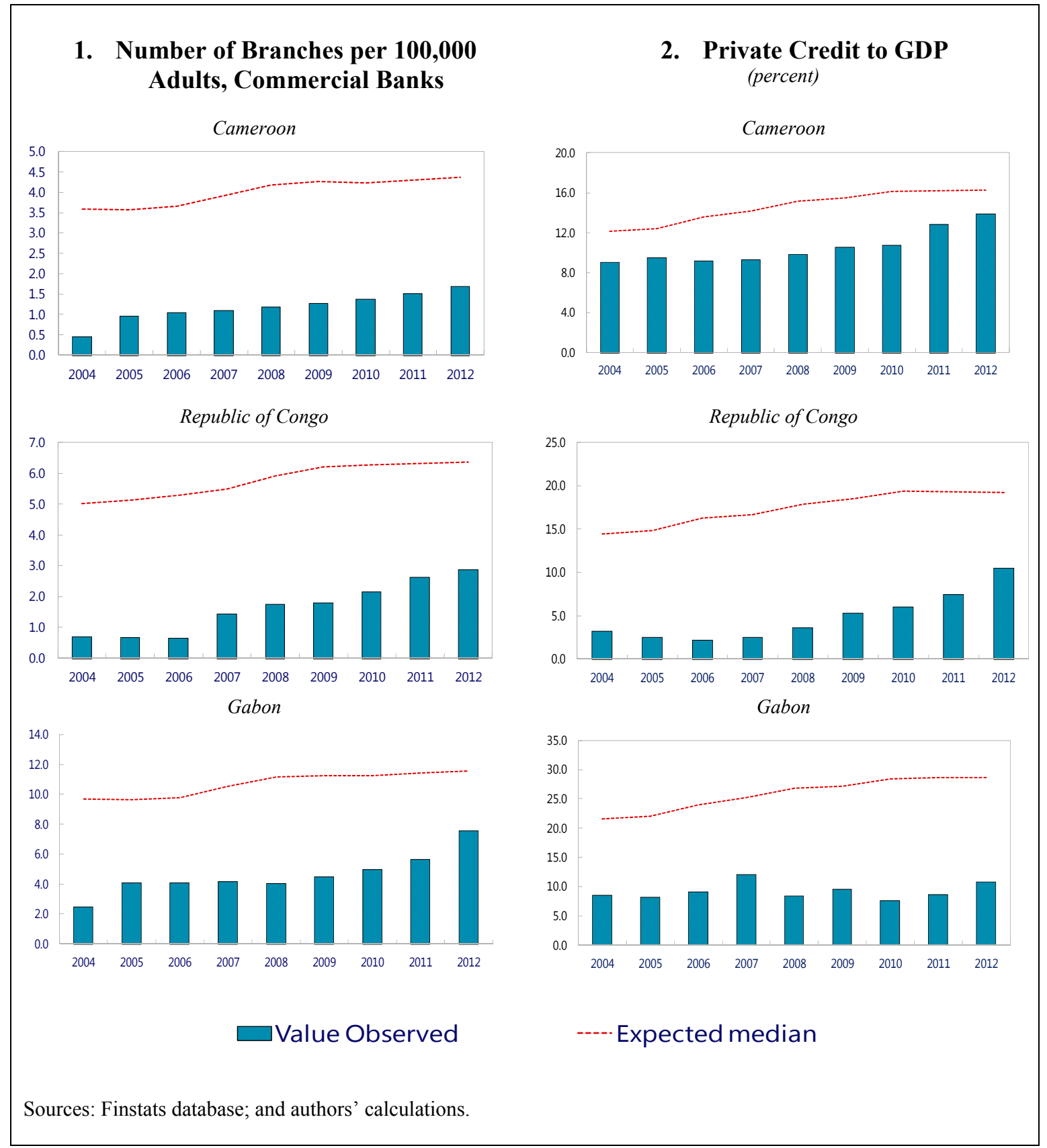

CInternational Monetary Fund. Not for Redistribution 


\section{THE DETERMINANTS OF FINANCIAL INCLUSION AND DEVELOPMENT IN THE CEMAC}

In this section we examine the determinants of financial inclusion and development in the CEMAC $^{11}$

\section{A. Data and methodology}

In our analysis, we use for each variable yearly observations during $1997-2012$. The country dimension covers 42 SSA countries. ${ }^{12}$ All variables are averaged over four-year non-overlapping intervals (i.e., 1997-2000; 2001-2004; 2005-2008; and 2009-2012) in line with Levine (2005). ${ }^{13}$ The summary statistics of the averaged data are presented in Table 4.

\section{Dependent variables}

Our dependent variables are the ratio of private credit to GDP and a measure of the financial development gap which we define as the ratio between the benchmark and actual private credit to GDP level (see also equation (2) below). Data limitations prevent us from being able to use the measure on bank branches and we therefore focus on credit to GDP as our primary measure of financial development. Although access and depth measures often have different focuses and are not theoretically perfect substitutes - notably because credit could be concentrated among a few large borrowers - they are highly correlated in our sample countries and factors associated with higher credit to GDP can be expected to be associated with larger measures of access to financial sectors (see Figure 3 and Table 7).

As described in Section II above, the benchmark financial development indicator is computed as the expected median of the private credit to GDP ratio obtained from yearly cross-country regressions. Figure 4 illustrates that most of the SSA countries deviate substantially from their benchmark, reflecting the underdevelopment of the financial sector. Given how we defined our measure of financial gap, a financial gap at unity indicates that country's financial development is at its expected level. A ratio above unity indicates that there is scope for policies to boost financial development.

\footnotetext{
${ }^{11}$ When looking at the determinants of financial development in CEMAC countries, we add a dummy reflecting their belonging to the CFA franc zone.

12 The 42 countries are: Angola, Benin, Botswana, Burkina Faso, Burundi, Cameroon, Cabo Verde, Central African Republic, Chad, Comoros, Democratic Republic of the Congo, Republic of Congo, Côte d'Ivoire, Equatorial Guinea, Eritrea, Gabon, The Gambia, Ghana, Guinea, Guinea-Bissau, Kenya, Lesotho, Liberia, Madagascar, Malawi, Mali, Mauritius, Mozambique, Namibia, Niger, Nigeria, Rwanda, São Tomé and Príncipe, Senegal, Seychelles, Sierra Leone, South Africa, Swaziland, Tanzania, Togo, Uganda, and Zambia.

13 The averaging procedure is widely used in the finance-growth literature to assess long-run relationships between macro-financial variables.
} 
Figure 3. Financial depth and access in sub-Saharan Africa (1997-2012, four-year averages)

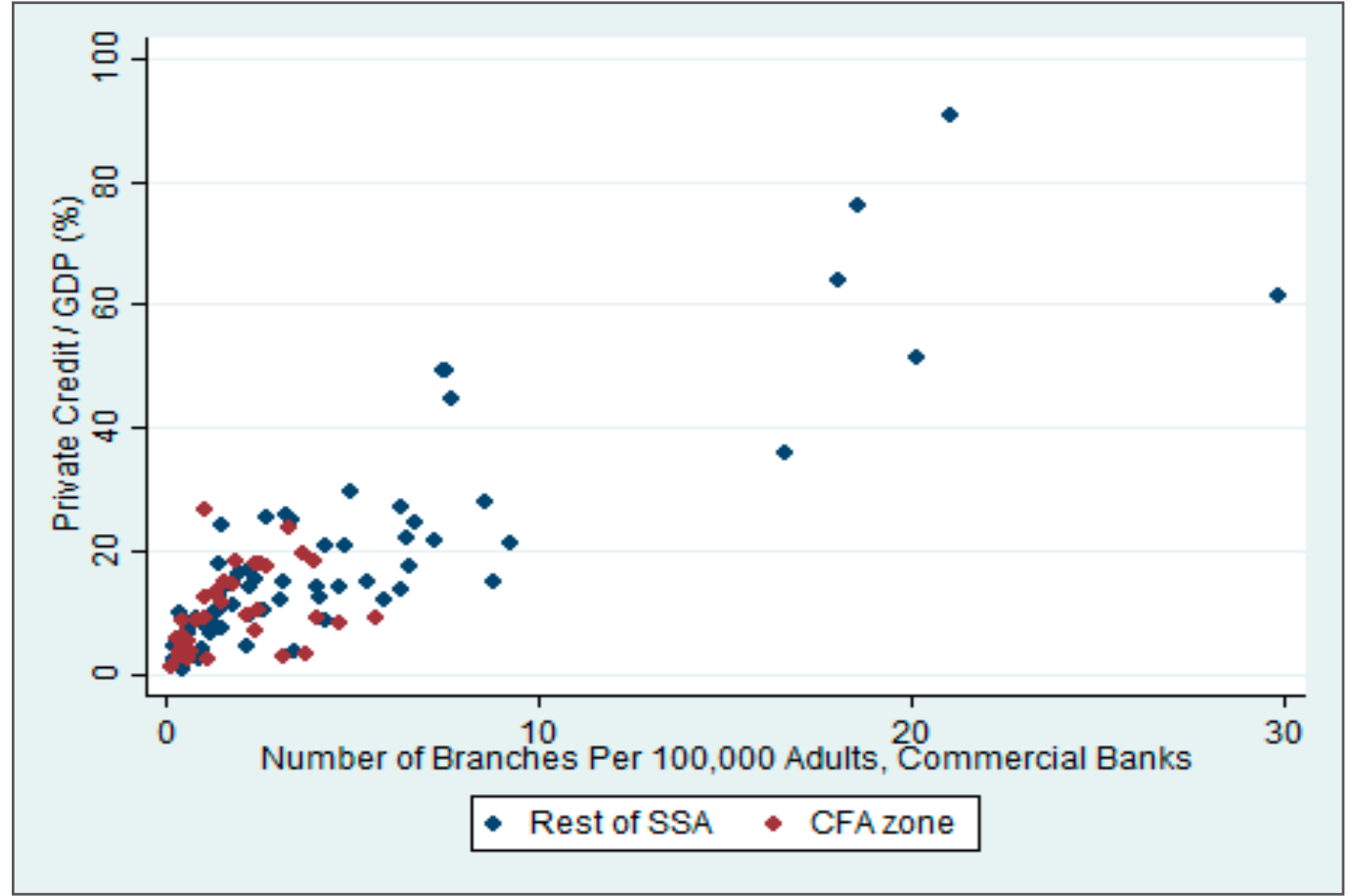

Sources: Finstats database; and authors' calculations.

Figure 4. Financial development gap in sub-Saharan Africa (2009-2012, average)

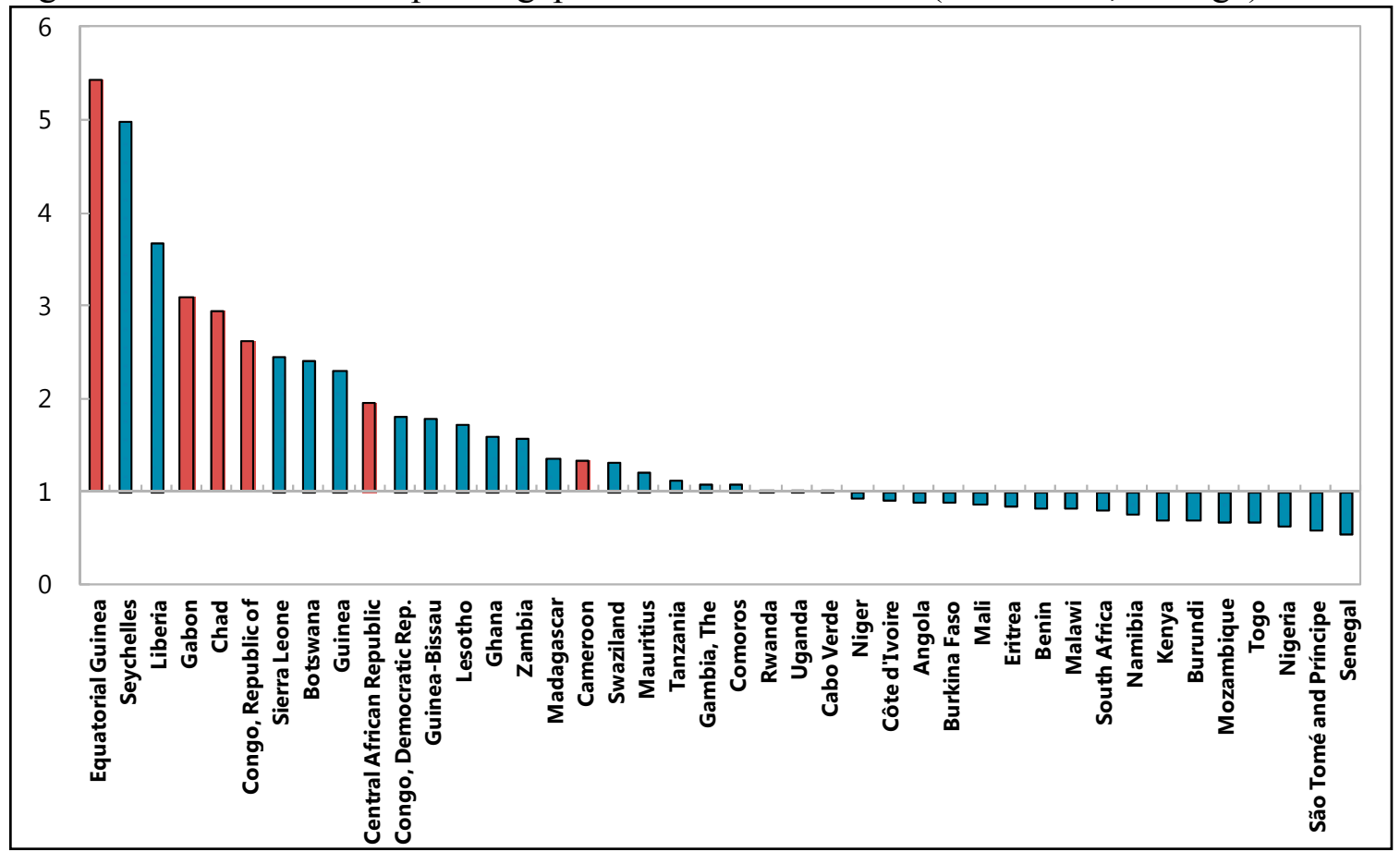

Note: A value higher than one reflects that countries have an underdeveloped financial sector (as proxied by private credit to GDP ratio) compared to their expected benchmark, given their state of macroeconomic development (e.g., income per capita levels, population). CEMAC countries are highlighted in red. Sources: FinStats database; and authors' calculations. 
As depicted in Figure 5, the average financial gap in SSA shrinks over time. However, it remains above the unity line highlighting that financial sectors in SSA are underdeveloped given countries' economic development and structural characteristics. The financial development gap is larger in CEMAC countries. This illustrates that some countries such as Equatorial Guinea and Gabon have experienced rapid GDP growth that has not translated into equally rapid financial sector growth.

Figure 5. Financial development gap in sub-Saharan Africa (country group averages)

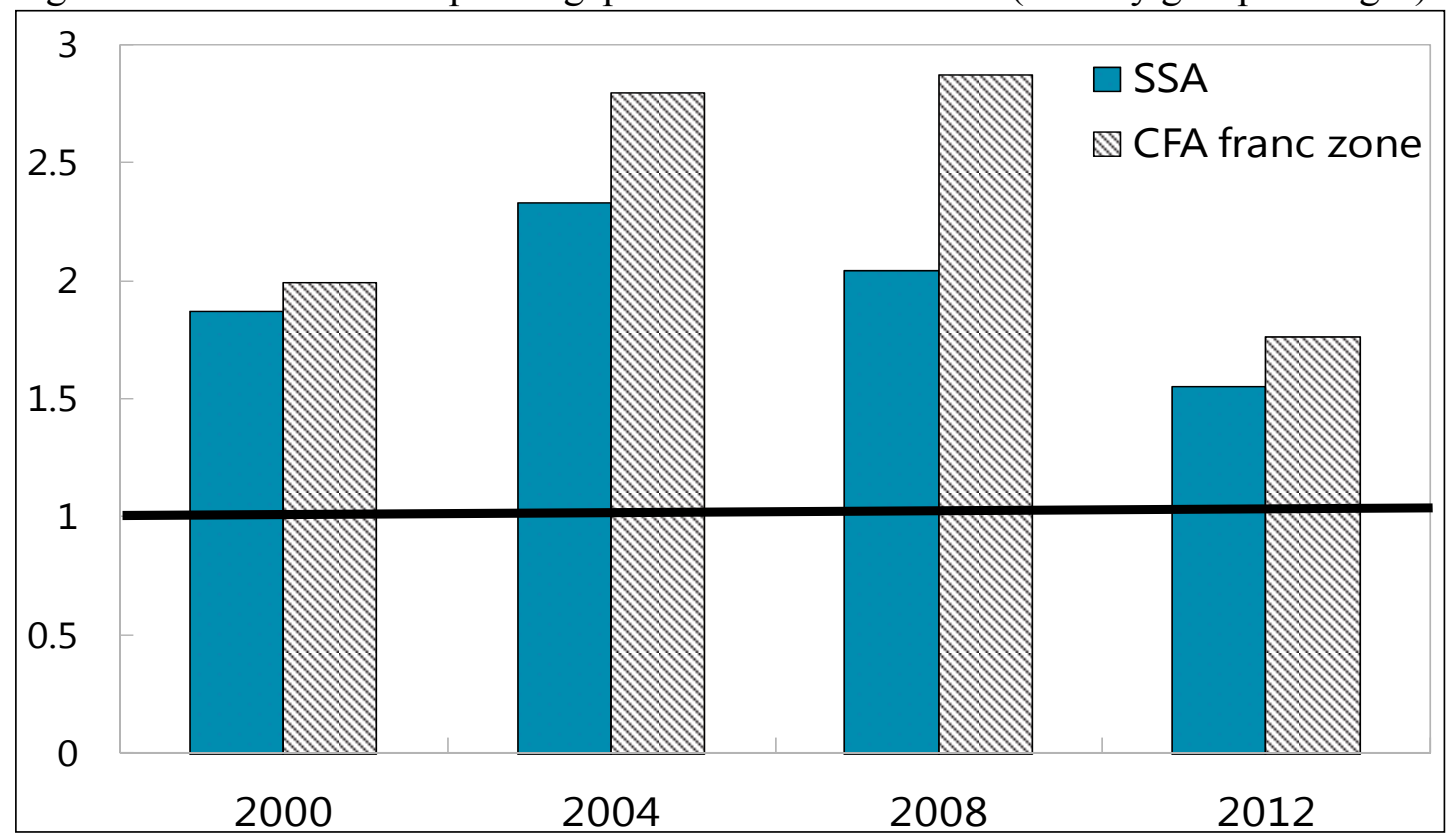

Note: The "Unit" line represents the equivalent of no development gap, meaning that the benchmark is equal to the actual private credit to GDP. Data points represent averages over the previous four years. (e.g. 2000 data points are the average of 1997-2000 observations for all countries in that group). Sources: FinStats database; and authors' calculations.

\section{Explanatory variables}

The theoretical and empirical literature has identified a very large set of potential determinants to explain financial sector development. Under the data availability constraint, we consider several categories of variables that could have an impact on financial sector development: macroeconomic, institutional, banking and financial sector specific, geography and population, technology related, and CFA franc zone specific.

\section{Macroeconomic variables}

Following the literature on the finance-growth nexus (see, e.g., Levine (2005)), we include several macroeconomic variables such as income per capita, inflation, debt-to-GDP ratio and natural resources GDP. The natural resource GDP represents the ratio of non-renewable resources GDP to total GDP. We expect higher income to be associated with more financial development. In contrast, we expect higher inflation, debt to GDP and resource GDP to contribute negatively to private credit to GDP and to increase the financial development gap. We use these variables in lags to address endogeneity issues. 


\section{Institutional variables}

We include three variables: government effectiveness, rule of law and political stability. We expect better institutions to be positively related to private credit-to-GDP, and negatively associated with the financial development gap. These variables are collected from the Worldwide Governance Indicators (WGI), and range between -2.5 and 2.5 depending on their worldwide rank. In our SSA sample, these variables have a negative mean, reflecting the poor institutional setup of this region.

\section{Banking infrastructure and financial sector-specific governance factors}

Another group of independent variables are related to banking infrastructure and banking systems' characteristics. Higher deposits, and lower interest rate spreads are expected to positively influence the developments in private credit-to-GDP ratio. Similarly a better institutional framework (e.g., registry coverage, depth of credit information) is expected to reduce information asymmetries between lenders and borrowers and, thus, boost financial development. Higher cost-to-income ratios and operational costs of banks are expected to be negatively associated with financial development as they increase the cost of lending.

\section{Geography and population}

Once we account for the size of the country, population density and the share of urban population are expected to positively influence access to financial services and financial development through allowing economies of scale. High poverty headcount and infant mortality are usually associated with lower income and lower financial inclusion.

\section{Technological advances}

We added two variables measuring the development of new technologies, namely mobile phone subscriptions and internet utilization rates, to assess their association with financial sector development.

\section{CFA franc zone specific variables}

We identify CEMAC by their belonging to the CFA franc zone. The law and finance literature (Beck and Levine, 2003) has illustrated how legal traditions affect institutional characteristics. Gupta, et al. (2009) have shown that the CFA franc zone countries had less developed financial sectors. We create a set of interaction variables for several institutional variables which we associate with a CFA franc zone dummy. For example, in the case of the CFA government effectiveness, this variable takes the value of the government effectiveness index for each member country of the CFA franc zone, and zero for the non-members.

\section{B. Empirical Model}

First, in order to understand what explains the financial underdevelopment in SSA, we investigate the determinants of private credit to GDP. ${ }^{14}$

\footnotetext{
${ }^{14}$ This proxy has been used extensively in the related literature (see Ahokpossi, et al. (2013), David, et al. (2014), Singh, et al. (2009)). Our results are very similar when using "deposits to GDP" ratio as a proxy for financial development.
} 
In our analysis we estimate the financial development as a function of macroeconomic variables and institutional, policy and financial system specific variables:

$$
F D_{i, t}=\alpha_{0}+X_{i, t} \beta+u_{t} \delta+\alpha_{i}+\epsilon_{i, t}
$$

Specifically, we use panel data analysis where $\alpha_{i}$ and $u_{t}$ are country and time fixed effects, respectively. These variables are used to control for country-invariant time-specific variables (e.g., commodity prices, global risk factors, global technology development) and unobserved time-invariant country-specific variables (e.g., geographic location, proximity to sea/ocean). Furthermore, $X_{i, t}$ are macroeconomic and structural variables (e.g., GDP per capita, inflation, natural resources GDP as percent of the total GDP, public debt, real GDP growth) and country-specific banking variables (e.g., deposits, cost to income ratio, interest rate spread, operational costs, return on assets). We augment our regression analysis with country-specific institutional and development variables (e.g., rule of law index, government effectiveness index, population density, population share below the poverty line). Moreover, we use several interaction variables (i.e. CFA* Rule of Law, CFA* Government Effectiveness, CFA* Political Stability, CFA* Deposits, CFA *Operational costs), to check whether institutional characteristics are influencing differently financial development in the CEMAC than in the rest of SSA. Finally $\alpha_{0}$ is a constant, $\beta$ and $\delta$ are vectors of regression coefficients, while $\epsilon_{i, t}$ are the error terms. We do not claim any clear causality direction between explanatory variables and the dependent ones. To address possible endogeneity issues, we first average all variables over four-year non-overlapping intervals and use lagged values for our macroeconomic regressors.

In the second step of our analysis we focus on the financial development gap. Although in our analysis we focus only on the SSA countries, by comparing each country's financial development with its benchmark, we intend to find the determinants of divergence from their worldwide peers. Thus we define the financial development gap as the ratio between the benchmark and the observed values for each country:

FinGap $_{i, t}=\frac{\text { Benchmark }_{i, t}}{F D_{i, t}}$;

The technical appendix describes how Benchmark_(i, t) is computed.

In order to find the determinants of the financial development gap in SSA, we regress the FinGap $_{i, t}$ (dependent variable) on macroeconomic, institutional, and banking-specific variables similar to equation (1):

$\operatorname{FinGap}_{i, t}=\alpha_{0}+X_{i, t} \beta+u_{t} \delta+\alpha_{i}+\epsilon_{i, t}$

In equation (3) we use a similar specification setup as in equation (1). For each of our sample countries, when some of the structural determinants of the financial development indicator represented by economic development factors together with population and demographic characteristics, special circumstances (e.g., natural resources exporters, offshore financial centers, countries in transition or landlocked) match exactly the benchmark then we have a ratio of one. When they differ then our gap measure can be explained by macroeconomic and structural variables and country-specific institutional and development variables. We include both country and time fixed effects to control for the omitted factors. 
For some variables, when we have on average only two observations per country, we use random effects panel analysis. The assumption for the random effects regressions is that regressors $\boldsymbol{X}_{\boldsymbol{i}, \boldsymbol{t}}$ are not correlated with individual-country effects $\alpha_{i}$, on top of being independent from time effects $u_{t}$, and error terms $\epsilon_{i, t}$, for all $i$ and $t$, which allows for timeinvariant variables to play a role as explanatory variables. ${ }^{15}$

\section{Results: The determinants of financial development}

In this section, we present the regression results of the impact of macroeconomic variables, institutional factors and structural characteristics on financial depth and the financial development gap. ${ }^{16}$

\section{Macroeconomic Variables}

Our results confirm that for our SSA sample, macroeconomic variables matter and behave as expected. Countries with higher income per capita have a more developed financial sector. Inflation is negatively and significantly correlated with credit to the private sector as is the share of natural resources. In the first set of regressions in Table 1, in which we study the impact on private credit to GDP, all three macroeconomic variables are significant and robust across all specifications. These factors explain most of the variation in private creditto-GDP ratio. As income increases, financial constraints (e.g., collateral, minimum income) are less binding while the demand for financial services increases. Higher inflation affects investment decisions as discount factor increases, thus affecting the demand for private credit, and also reduces the return on lending. Moreover, in a high inflation environment households are reluctant to save and focus their consumption on the short-term. As expected, a higher share of natural resource GDP is associated with a less developed financial sector and hitherto a larger gap from the benchmark. First because often revenues from natural resources can mechanically boost a country's GDP beyond a its overall level of economic and financial development and second since most of the oil and mining companies investing in developing countries are foreign conglomerates, they may be tapping financing sources from overseas where financial sectors are already better performing. Table 3 shows that among CFA franc zone countries, a larger share of natural resources GDP is associated with a larger gap from the country's benchmark; this is consistent with the differences in the financial sector development levels between WAEMU and CEMAC.

Interestingly, the country's income level is an insignificant determinant of the financial gap. As shown in Table 2, we find no linear relationship between the financial gap and income per capita; richer and poorer countries may be equally far from their expected financial development levels. Previous period inflation remains significant: as shown by the $\mathrm{R}^{2}$ of regression (3), almost 30 percent of the financial gap is explained by lagged inflation.

\footnotetext{
${ }^{15}$ This assumption was checked for robustness.

${ }^{16}$ For each dependent variable we provide fixed effects regressions with robust standard errors. In order to maximize the size of our sample, when independent variables have less than 100 observations (the equivalent of less than 3 time-period observations per country) we provide estimation results based on panel regressions with random effects.
} 
Consistent with the previous regression setup, higher inflation is associated with a higher gap, i.e. a less developed financial sector.

\section{Institutional variables}

Looking beyond macroeconomics and variables such as inflation and income, and turning to the impact of institutional variables, we find a significant relationship between financial gap and rule of law for all SSA countries. This result is in line with Ahokpossi, et al. (2013) who show that the difference in rule of law explains the performance lag of financial sectors in the WAEMU compared to a benchmark group In addition, when looking more specifically at the CFA franc zone, we find that CFA franc zone countries with better government effectiveness and property rights appear to have a more developed financial system. Table 3 introduces several interaction variables with the CFA franc zone countries.

\section{Financial sector variables}

In contrast, variables related to the financial sector infrastructure and governance affect the financial sector development in all SSA countries. They explain not only the level of financial development but are also a significant determinant of the financial gap. Higher deposits are associated with higher private credit to GDP ratio, since availability of funding for these institutions is crucial. In Table 1, a one percent increase in deposits translates into a 0.4 percent increase in private credit. ${ }^{17}$ Higher operational costs and cost-income ratio affect negatively the growth of financial development as high operational costs may be transferred to the clients, and demand for loans reduced. The performance of the regressions improves when we add financial sector variables. The highest $\mathrm{R}^{2}$ found in Table 1 is around 66 percent when income per capita, inflation, natural resource GDP, deposits and banks' costincome ratio are jointly included (regression (7)). These results are consistent with Table 2 which shows that deposits-to-GDP ratio, and banks' operational costs are important determinants in explaining the financial development gap: higher operational costs are associated with a wider gap. On the other hand, the financial gap narrows as the share of deposits to GDP increases.

As shown in Table 1 and Table 2, better information availability (i.e. credit information depth and credit registry coverage) are found to be positively associated with financial development and to significantly narrow the underdevelopment gap. Credit registry coverage and the depth of credit information address information asymmetries between lenders and borrowers and, thus, improve prospects for financial development. These results highlight the need for structural reforms and the improvement of institutional framework.

\section{Population characteristics}

In line with Allen, et al. (2014), we find we find total population (log) in negative relationship with the financial gap. This result might be driven by countries with high populations like South Africa and Nigeria in which financial sectors are relatively more developed than the rest of SSA. Economies of scale are another possible explanation for this result. We also find that poverty and the financial development gap are positively related.

\footnotetext{
17 These results remain consistent in magnitude and significance, when lagged independent variables are utilized.
} 
This is consistent with the negative relationship between financial development and poverty as poverty headcount (shown in Table 1, regression (12); or proxied by infant mortality in Table 2, regression (7)), which confirms the need for measures to make financial services more inclusive.

\section{Technological advances}

Power consumption per capita is found to be significant and is positively related to the level of financial development (Table 1, regression (11)). However, when including per capita power consumption, income per capita becomes insignificant. Since power consumption is associated with economic development and is highly correlated with income, it captures the income related effect.

\section{Attribution analysis}

The effects depicted in Figure 6 show that an improvement in Rule of Law could decrease the financial development gap by about 15 percentage points, while natural resources and inflation deteriorate the gap by about 7 and 14 percentage points, respectively.

Figure 6. Effects of Macroeconomic and Institutional Factors on Financial Gap

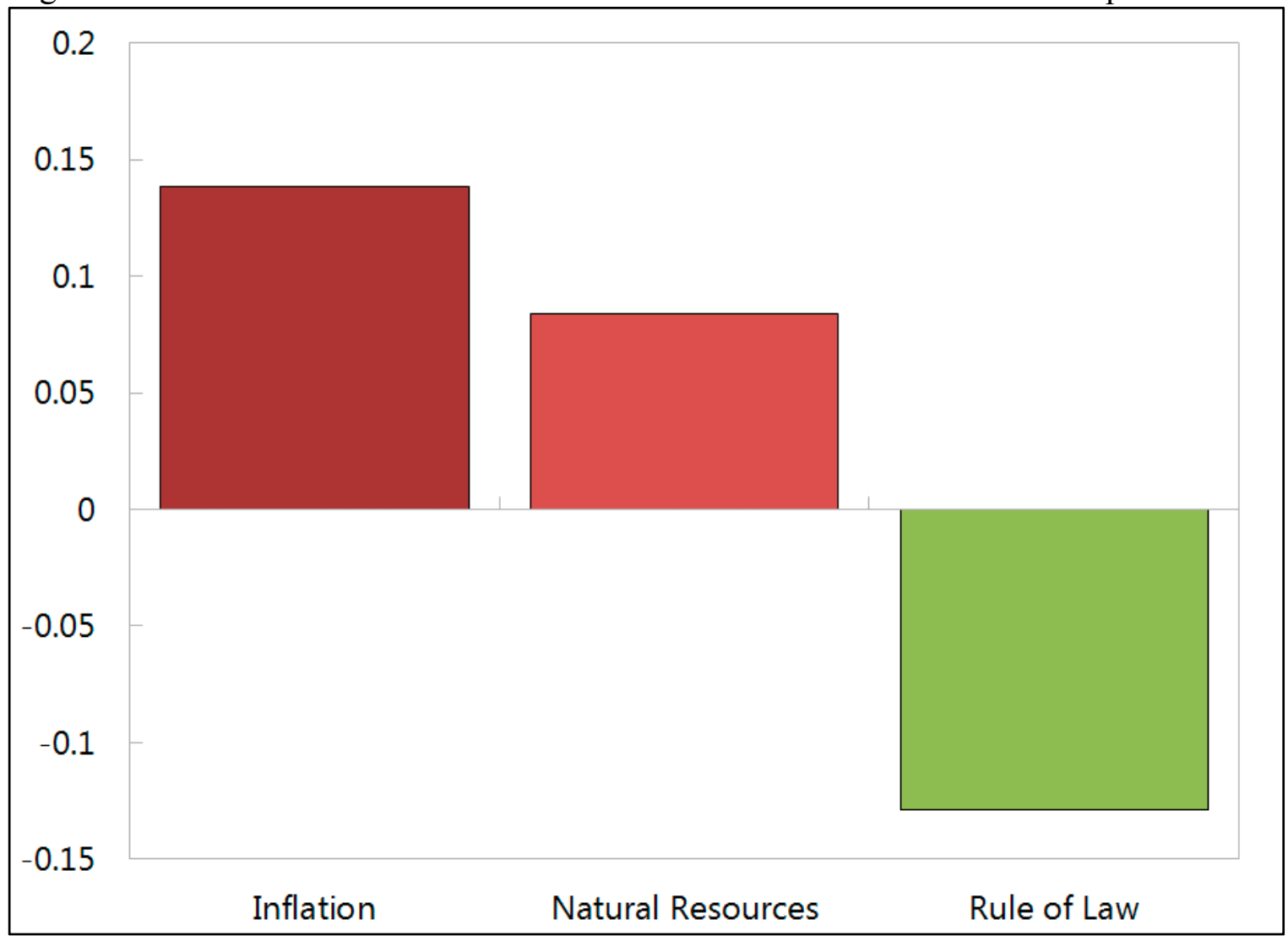

Note: The bars show the effect of one standard deviation increase in each variable on the financial development gap as depicted in Table 2, regression (11). These are calculated by multiplying the estimated coefficient of the regression and the standard deviation of the corresponding regressor. We control for global conditions by including a time trend.

Sources: FinStats database; and authors' calculations. 


\section{Peers And Policies}

Our regression results show that beyond ensuring macroeconomic stability, institutional factors and financial sector characteristics can affect financial development. Better financial sector institutions, better quality of credit information and improved governance can contribute to promote financial sector development. ${ }^{18}$ To identify what specific policy measures could help CEMAC countries to increase financial inclusion, we identify best performers among their "peers". Peer countries are listed in Table 11 (Appendix). Selected countries have similar population size and economic development as CEMAC countries. Among those peers, Mozambique, Rwanda and Kenya have made rapid progress in widening access to financial services in recent years (Figure 7).

The public policy agenda should include measures to address the main supply barriers to financial access. A national or regional strategy needs to be set up with measurable targets and a coordinating institution. For example, in Rwanda, the authorities launched the Financial Sector Development Program (FSDP) in 2006 aiming among others at extending financial services to the unbanked. In 2008, 52 percent of Rwandan adults (18 years or older) did not use any financial product or service. This number dropped to 28 percent in 2012 (FinStats). This inclusion improvement was likely driven by an uptake of banking products, and of products offered by non-bank formal financial institutions and in particular the newly created savings and credit cooperatives (SACCOs) which have substantially increased financial inclusion and development. These new institutions have been successful in providing formal financial services to Rwandans who would otherwise not use formal financial services. In Kenya, Allen, et al. (2012) find that the development of Equity Bank, a commercial bank focused on the microfinance segment has significantly helped increase the proportion of households that have access to a bank account. A common feature between the Rwandan SACCOs and the Kenyan Equity Bank lies in only requiring photo ID for opening a bank account and they do not require a minimum balance. This strategy has also been followed in South Africa where the regulator has imposed a type of free bank accounts. At the same time, it remains paramount to protect the consumers and ensure proper supervision of innovative banking or microfinance. In particular, the efforts to create a good environment for microfinance and mobile banking should continue by fostering collaboration between commercial banks and microfinance institutions and telecommunication companies. Improving legislation, property rights and documentation should enhance access to finance.

Regulations should foster innovative finance such as mobile banking as they lower transaction costs and will allow offering financial services at lower costs, thereby widening their usage. Technology has helped reduce exclusion rates in Kenya and Tanzania, where the regulators have implemented the interoperability among providers, thereby promoting competition and reducing costs. Moreover, they allowed mobile-money-based cross-border remittances.

\footnotetext{
${ }^{18}$ Worldwide, more than half of financial regulatory frameworks include measures for promoting financial inclusion and a set of relevant best practices can be identified.
} 
Figure 7. Benchmarking financial development in selected peer countries (2004 -2012)

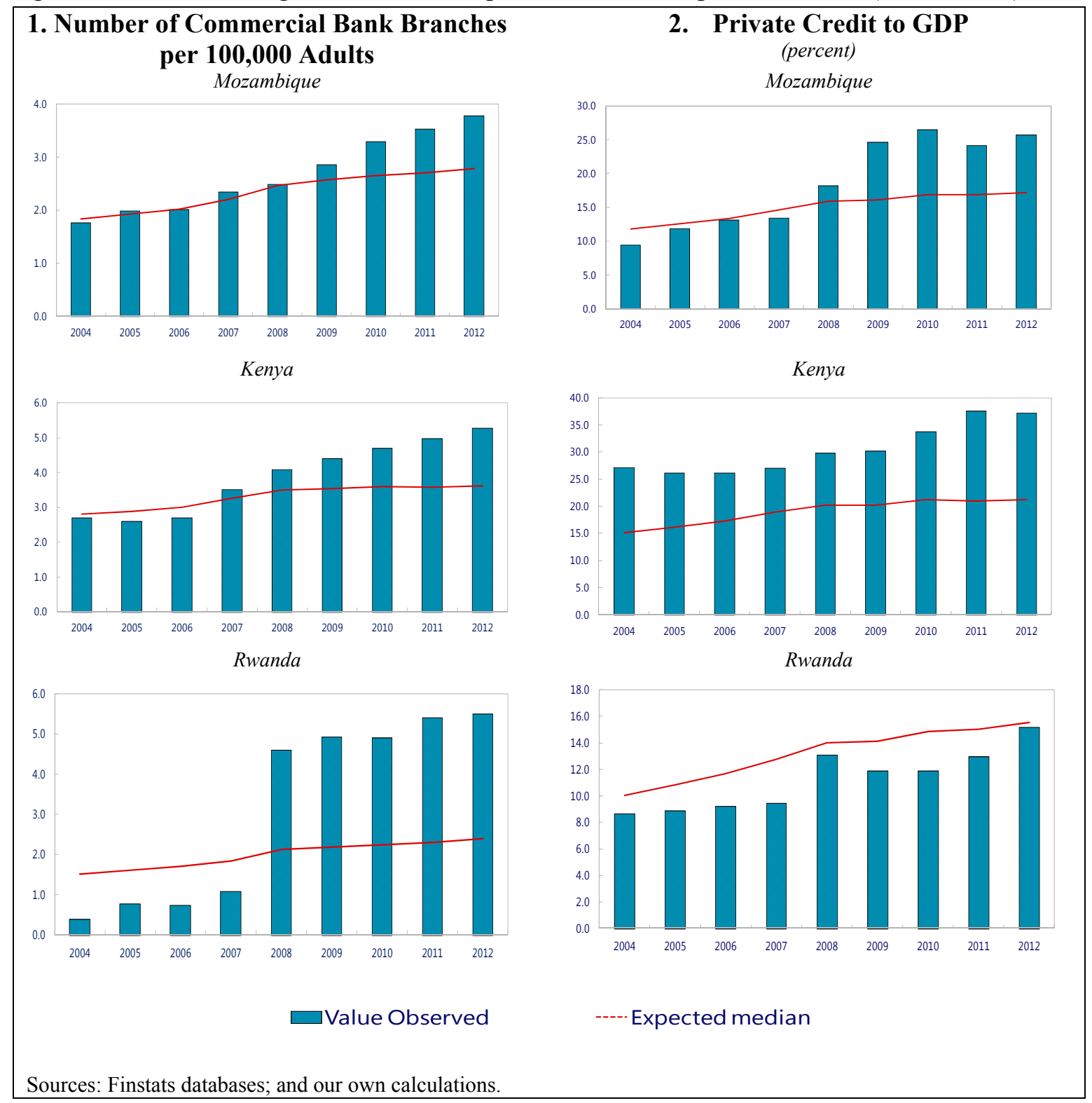

The ongoing implementation of the electronic payment system for taxes and utilities has to move forward and expansion of banking branch networks should be encouraged. Further reforms should aim to improve the business environment and judicial framework, boost supervision capacities, reduce asymmetry of information, and facilitate loan recovery. These measures could boost the financing of new investments and growth. 


\section{Conclusion}

While financial development and in particular, financial inclusion, matters for social and economic development, progress across SSA has been very uneven. Financial sectors in CFA franc zone countries remain relatively shallow and exclusive. Looking at the factors that hinder or promote financial deepening and inclusion, we confirm that macroeconomic stability is a prerequisite but also identify that governance and in particular financial sector characteristics matter. In particular, we find that macro variables like inflation, income, and natural resources explain most of the private credit to GDP ratio (our proxy for financial development). Financial development is positively linked to the number of bank branches, availability of credit information, and registry coverage, but negatively impacted by banks' operational costs, cost-income ratio, and poverty headcount. Our results suggest that inflation, new technology, and operational costs are important determinants of the financial development gap in Africa. Moreover, CFA franc zone countries with stronger institutions, where factors such as government effectiveness and property rights are concerned, developed more inclusive financial systems. Improved financial supervision and financial sector governance contribute to promoting financial sector development. Measures to improve the availability of credit information could boost the likelihood of financial development.

Interestingly, we also find that income does not explain the financial development gap; richer and poorer countries may be equally far from their expected financial development levels. As there is scope for policy actions and structural reform for all countries, turning to best practices among peer countries with a proven track record of recent reform could help CFA franc zone countries to develop their financial sector in an inclusive, sound and sustainable manner. Finally, we use peer countries to identify policies that could improve financial inclusion. Supported by our findings, policies focused on financial inclusion should help to alleviate poverty 


\section{BIBLIOGRAPHY}

Ahokpossi, C., Ismail, K., Karmakar, S., \& Koulet-Vickot, M. (2013). Financial Depth in the WAEMU: Benchmarking Against Frontier SSA Countries. IMF Working Paper $W P / 13 / 161$.

Allen, F., Carletti, E., Cull, R., Qian, J., Senbet, L., \& Valenzuela, P. (2012). Resolving the African Financial Development Gap: Cross-Country Comparisons and a WithinCountry Study of Kenya. NBER volume on African Economic Successes.

Allen, F., Carletti, E., Cull, R., Qian, J., Senbet, L., \& Valenzuela, P. (2014). The African Financial Development and Financial Inclusion Gaps. Journal of African Economies, $1-29$.

Arcand, J.-L., Berkes, E., \& Panizza, U. (2012). Too Much Finance? IMF Working Paper $W P / 12 / 161$.

Beck, T., Demirgüç-Kunt, A., \& Levine, R. (2007). "Finance, inequality and the Poor. Journal of Economic Growth, vol. 12(1, 27-49.

Beck, T., Feyen, E., Ize, A., \& Moizeszowicz, F. (2008). Benchmarking Financial Development. World Bank Policy Working Paper 4638.

Boyd, J., Levine, R., \& Smith, B. (2001). The Impact of Inflation on Financial Sector Performance. Journal of Monetary Economics, 47, 221-48.

Burgess, R., \& Pande, R. (2005). Do Rural Banks Matter? Evidence from the Indian Social Banking Experiment. American Economic Review, 95(3), 780-795.

Čihák, M., Demirgüç-Kunt, A., Feyen, E., \& Levine, R. (2012). Benchmarking Financial Systems around the World. World Bank Policy Research Working Paper 6175.

Dabla Norris, E., Ji, Y., Townsend, R., \& Unsal, D. F. (2014). Financial Deepening, Growth, and Inequality: A Structural Framework for Developing Countries. IMF Working Papers.

David, A., Mlachila, M., \& Moheeput, A. (2014). Does Openness Matter for Financial Development in Africa? IMF Working Paper WP/14/94.

Demetriades, P., \& Fielding, D. (2011). Information, Institutions and Banking Sector Development in West Africa. Western Economic Association International.

Demirgüç-Kunt, A., \& Klapper, L. (2013). Measuring Financial Inclusion: Explaining Variation in Use of Financial Services across and within Countries. Brookings Papers on Economic Activity, 1, 279-340.

Detragiache, E., Gupta, P., \& Tressel, T. (2005). Finance in Lower-Income Countries: An Empirical Exploration. IMF Working Paper.

Finscope. (2012). Financial Inclusion in Rwanda 2008 - 2012.

IMF. (2015). Rethinking Financial Deepening: Stability and Growth in Emerging Markets. $S D N / 15 / 08$.

King, R. G., \& Levine, R. (1993). Finance and growth : Schumpeter might be right. Quarterly Journal of Economics, 108, 717-738.

King, R. G., \& Levine, R. (1993). Finance, entrepreneurship, and growth: Theory and evidence. Journal of Monetary Economics, 108, 513-542. 
Levine, R. (2005). Finance and Growth: Theory and Evidence. In P. A. (ed.), Handbook of Economic Growth (pp. 865-934). Elsevier.

Murinde, V. (2012). Financial Development and Economic Growth: Global and African Evidence. Journal of African Studies, 21, i10-i56.

Piketty, T. (2003). Income Inequality in France, 1901-1998. Journal of Political Economy, 111(5), 1004-1042.

Rajan, R., \& Zingales, L. (1998). Financial Dependence and Growth. American Economic Review, 88, 559-586.

Singh, R. J., Kpodar, K., \& Ghura, D. (2009). Financial Deepening in the CFA Franc Zone: The Role of Institutions. IMF Working Paper WP/09/113.

World Bank. (2014). Global Financial Development Report. 


\section{APPENDIX}

Table 1 Determinants of Private Credit in SSA

\begin{tabular}{|c|c|c|c|c|c|c|c|c|c|c|c|c|}
\hline $\begin{array}{l}\text { VARIABLES } \\
\text { (period averages) }\end{array}$ & $\begin{array}{l}\text { Expected } \\
\text { sign }\end{array}$ & $\begin{array}{c}(1) \\
\text { Private } \\
\text { Credit / GDP } \\
(\%)\end{array}$ & $\begin{array}{c}(2) \\
\text { Private } \\
\text { Credit / GDP } \\
(\%)\end{array}$ & $\begin{array}{c}(3) \\
\text { Private } \\
\text { Credit / GDP } \\
(\%)\end{array}$ & $\begin{array}{c}(4) \\
\text { Private } \\
\text { Credit / GDP } \\
(\%)\end{array}$ & $\begin{array}{c}(5) \\
\text { Private } \\
\text { Credit / GDP } \\
(\%)\end{array}$ & $\begin{array}{c}(6) \\
\text { Private } \\
\text { Credit / GDP } \\
(\%)\end{array}$ & $\begin{array}{c}(7) \\
\text { Private } \\
\text { Credit / GDP } \\
(\%)\end{array}$ & $\begin{array}{c}(8) \\
\text { Private } \\
\text { Credit / GDP } \\
(\%)\end{array}$ & $\begin{array}{c}(9) \\
\text { Private } \\
\text { Credit / GDP } \\
(\%)\end{array}$ & $\begin{array}{c}(10) \\
\text { Private } \\
\text { Credit / GDP } \\
(\%)\end{array}$ & $\begin{array}{c}(11) \\
\text { Private } \\
\text { Credit / GDP } \\
(\%)\end{array}$ \\
\hline & & \multicolumn{6}{|c|}{ Fixed Effects } & \multicolumn{5}{|c|}{ Random Effects } \\
\hline log GDP per capita (lag) & + & $\begin{array}{c}9.305^{* * *} \\
(2.369)\end{array}$ & $\begin{array}{c}9.227^{* * *} \\
(2.349)\end{array}$ & $\begin{array}{l}9.586 * * * \\
(3.018)\end{array}$ & $\begin{array}{l}8.943^{* * *} \\
(2.170)\end{array}$ & $\begin{array}{c}7.291 * * * \\
(1.593)\end{array}$ & $\begin{array}{c}7.501^{* * *} \\
(1.520)\end{array}$ & $\begin{array}{c}8.945^{* * *} \\
(2.466)\end{array}$ & $\begin{array}{c}9.145^{* * *} \\
(2.891)\end{array}$ & $\begin{array}{c}8.782^{* * *} \\
(2.922)\end{array}$ & & \\
\hline $\begin{array}{l}\text { Consumer Prices, (lag, } \\
\% \text { change) }\end{array}$ & - & $\begin{array}{c}-0.0449 * * * \\
(0.00852)\end{array}$ & $\begin{array}{c}-0.0420^{* * *} \\
(0.00884)\end{array}$ & $\begin{array}{c}-0.0332^{* *} \\
(0.0154)\end{array}$ & $\begin{array}{c}-0.0521^{* * *} \\
(0.0102)\end{array}$ & $\begin{array}{c}-0.0352^{* * *} \\
(0.00702)\end{array}$ & $\begin{array}{c}-0.0403^{* * *} \\
(0.00709)\end{array}$ & $\begin{array}{c}-0.0461^{* * *} \\
(0.00763)\end{array}$ & $\begin{array}{r}-0.00629 \\
(0.0200)\end{array}$ & $\begin{array}{l}-0.00124 \\
(0.0232)\end{array}$ & $\begin{array}{l}-0.0358^{*} \\
(0.0208)\end{array}$ & $\begin{array}{l}-0.0474 \\
(0.0436)\end{array}$ \\
\hline $\begin{array}{l}\text { Natural Resource GDP/ } \\
\text { Total GDP (lag) }\end{array}$ & - & $\begin{array}{c}-0.224^{* * *} \\
(0.0505)\end{array}$ & $\begin{array}{c}-0.211 * * * \\
(0.0522)\end{array}$ & $\begin{array}{l}-0.239 * * * \\
(0.0492)\end{array}$ & $\begin{array}{l}-0.191^{* * *} \\
(0.0432)\end{array}$ & $\begin{array}{c}-0.161^{* * *} \\
(0.0365)\end{array}$ & $\begin{array}{c}-0.153^{* * *} \\
(0.0342)\end{array}$ & $\begin{array}{c}-0.250^{* * *} \\
(0.0688)\end{array}$ & $\begin{array}{c}-0.392^{* * *} \\
(0.116)\end{array}$ & $\begin{array}{c}-0.369 * * * \\
(0.113)\end{array}$ & $\begin{array}{l}-0.0991 \\
(0.0657)\end{array}$ & $\begin{array}{l}-0.119 * * \\
(0.0504)\end{array}$ \\
\hline $\begin{array}{l}\text { Domestic Bank Deposits / } \\
\text { GDP (\%, lag) }\end{array}$ & + & & & & $\begin{array}{c}0.400^{* * *} \\
(0.128)\end{array}$ & & $\begin{array}{l}0.266^{*} \\
(0.137)\end{array}$ & & & & & \\
\hline $\begin{array}{l}\text { Bank cost / } \\
\text { income (\%) }\end{array}$ & - & & & & & $\begin{array}{l}-0.109^{* *} \\
(0.0514)\end{array}$ & $\begin{array}{c}-0.0916^{* *} \\
(0.0452)\end{array}$ & & & & & \\
\hline Government effectiveness & + & & $\begin{array}{c}5.817 \\
(5.226)\end{array}$ & & & & & & & & & \\
\hline $\begin{array}{l}\text { Overhead Costs / Total } \\
\text { Assets (\%) }\end{array}$ & - & & & $\begin{array}{l}-0.947 * \\
(0.516)\end{array}$ & & & & & & & & \\
\hline $\begin{array}{l}\text { Public registry coverage } \\
\text { (\% adults) }\end{array}$ & + & & & & & & & & $\begin{array}{c}0.425^{* * *} \\
(0.107)\end{array}$ & & & \\
\hline Credit information depth & + & & & & & & & & & $\begin{array}{c}1.317 \\
(0.927)\end{array}$ & & \\
\hline $\begin{array}{l}\text { Electricity consumption } \\
\text { per capita (lag) }\end{array}$ & + & & & & & & & & & & $\begin{array}{l}0.0112^{* *} \\
(0.00488)\end{array}$ & \\
\hline Poverty Headcount (\%) & - & & & & & & & & & & & $\begin{array}{c}-0.378 * * * \\
(0.0914)\end{array}$ \\
\hline Year $=2008$ & & $\begin{array}{l}2.185^{* *} \\
(0.827)\end{array}$ & $\begin{array}{r}2.467^{* *} \\
(0.919)\end{array}$ & $\begin{array}{l}1.752^{* *} \\
(0.799)\end{array}$ & $\begin{array}{l}0.742 \\
(0.755)\end{array}$ & $\begin{array}{c}2.174 * * * \\
(0.782)\end{array}$ & $\begin{array}{l}1.335^{* *} \\
(0.646)\end{array}$ & $\begin{array}{c}2.294^{* * *} \\
(0.826)\end{array}$ & & & $\begin{array}{l}1.814^{* *} \\
(0.875)\end{array}$ & \\
\hline Year $=2012$ & & $\begin{array}{c}2.425 \\
(1.866)\end{array}$ & $\begin{array}{c}2.741 \\
(1.880)\end{array}$ & $\begin{array}{l}1.298 \\
(1.804)\end{array}$ & $\begin{array}{c}0.187 \\
(1.602)\end{array}$ & $\begin{array}{l}3.521^{* *} \\
(1.458)\end{array}$ & $\begin{array}{l}1.920^{*} \\
(1.059)\end{array}$ & $\begin{array}{r}2.718^{* *} \\
(1.338)\end{array}$ & $\begin{array}{l}-0.188 \\
(1.314)\end{array}$ & $\begin{array}{c}0.337 \\
(1.127)\end{array}$ & $\begin{array}{c}4.740 * * \\
(2.138)\end{array}$ & \\
\hline Constant & & $\begin{array}{c}-42.48^{* * *} \\
(14.32)\end{array}$ & $\begin{array}{c}-37.97^{* *} \\
(14.59)\end{array}$ & $\begin{array}{l}-37.73^{*} \\
(19.59)\end{array}$ & $\begin{array}{c}-48.42 * * * \\
(12.82)\end{array}$ & $\begin{array}{c}-24.02^{* *} \\
(9.912)\end{array}$ & $\begin{array}{c}-31.24 * * * \\
(8.699)\end{array}$ & $\begin{array}{c}-40.31 * * * \\
(13.77)\end{array}$ & $\begin{array}{c}-38.86^{* *} \\
(16.57)\end{array}$ & $\begin{array}{c}-38.26^{* *} \\
(16.96)\end{array}$ & $\begin{array}{c}13.10^{* * *} \\
(2.099)\end{array}$ & $\begin{array}{c}35.33^{* * *} \\
(5.621)\end{array}$ \\
\hline Observations & & 119 & 119 & 106 & 118 & 107 & 106 & 119 & 79 & 80 & 51 & 64 \\
\hline Number countries & & 41 & 41 & 38 & 40 & 39 & 38 & 41 & 40 & 41 & 18 & 39 \\
\hline Frac. group variance & & 0.889 & 0.877 & 0.925 & 0.897 & 0.937 & 0.928 & 0.883 & 0.896 & 0.925 & 0.809 & 0.808 \\
\hline R2 within & & 0.491 & 0.506 & 0.616 & 0.591 & 0.618 & 0.663 & & & & & \\
\hline $\mathrm{R} 2$ between & & 0.349 & 0.442 & 0.388 & 0.544 & 0.334 & 0.517 & & & & & \\
\hline
\end{tabular}

CInternational Monetary Fund. Not for Redistribution 
Table 2. Determinants of financial development gap in SSA

\begin{tabular}{|c|c|c|c|c|c|c|c|c|c|c|c|c|c|c|}
\hline $\begin{array}{l}\text { VARIABLES } \\
\text { (period averages) }\end{array}$ & $\begin{array}{c}\text { Expected } \\
\text { Sign } \\
\end{array}$ & $\begin{array}{c}1) \\
\text { Financial } \\
\text { Gap } \\
\end{array}$ & $\begin{array}{c}\text { (2) } \\
\text { Financial } \\
\text { Gap } \\
\end{array}$ & $\begin{array}{c}\text { (3) } \\
\text { Financial } \\
\text { Gap }\end{array}$ & $\begin{array}{c}(4) \\
\text { Financial } \\
\text { Gap }\end{array}$ & $\begin{array}{c}\text { (5) } \\
\text { Financial } \\
\text { Gap } \\
\end{array}$ & $\begin{array}{c}\text { (6) } \\
\text { Financial } \\
\text { Gap }\end{array}$ & $\begin{array}{c}\text { (7) } \\
\text { Financial } \\
\text { Gap }\end{array}$ & $\begin{array}{c}(8) \\
\text { Financial } \\
\text { Gap }\end{array}$ & $\begin{array}{c}\text { (9) } \\
\text { Financial } \\
\text { Gap } \\
\end{array}$ & $\begin{array}{c}(10) \\
\text { Financial } \\
\text { Gap }\end{array}$ & $\begin{array}{c}(11) \\
\text { Financial } \\
\text { Gap }\end{array}$ & $\begin{array}{c}(12) \\
\text { Financial } \\
\text { Gap }\end{array}$ & $\begin{array}{c}(13) \\
\text { Financial } \\
\text { Gap } \\
\end{array}$ \\
\hline & & \multicolumn{8}{|c|}{ Fixed Effects } & \multicolumn{5}{|c|}{ Random Effects } \\
\hline log GDP per capita (lag) & $+/-$ & $\begin{array}{l}0.0355 \\
(1.055)\end{array}$ & $\begin{array}{c}0.332 \\
(1.453)\end{array}$ & $\begin{array}{l}-0.283 \\
(0.974)\end{array}$ & $\begin{array}{l}-0.229 \\
(0.328)\end{array}$ & $\begin{array}{l}0.0375 \\
(1.103)\end{array}$ & $\begin{array}{l}0.0269 \\
(0.337)\end{array}$ & & $\begin{array}{l}-0.0638 \\
(0.329)\end{array}$ & $\begin{array}{c}0.160 \\
(0.187)\end{array}$ & & & & \\
\hline $\begin{array}{l}\text { Consumer Prices, (lag, } \\
\% \text { change) }\end{array}$ & + & & & $\begin{array}{l}0.0212^{* *} \\
(0.00816)\end{array}$ & $\begin{array}{c}0.00615 \\
(0.00419)\end{array}$ & $\begin{array}{l}0.0191 * * \\
(0.00842)\end{array}$ & $\begin{array}{c}0.00473 \\
(0.00448)\end{array}$ & $\begin{array}{c}0.00430 \\
(0.00434)\end{array}$ & $\begin{array}{c}0.00388 \\
(0.00408)\end{array}$ & $\begin{array}{l}0.0195^{* * *} \\
(0.00704)\end{array}$ & $\begin{array}{c}0.000275 \\
(0.0129)\end{array}$ & $\begin{array}{l}0.0171^{* *} \\
(0.00775)\end{array}$ & $\begin{array}{l}-0.00196 \\
(0.00579)\end{array}$ & $\begin{array}{l}0.0188^{* *} \\
(0.00742)\end{array}$ \\
\hline $\begin{array}{l}\text { Natural Resource GDP/ } \\
\text { Total GDP(lag) }\end{array}$ & + & & $\begin{array}{l}-0.0143 \\
(0.0250)\end{array}$ & $\begin{array}{c}0.00968 \\
(0.00825)\end{array}$ & $\begin{array}{l}0.00568 \\
(0.0151)\end{array}$ & $\begin{array}{l}0.00346 \\
(0.0108)\end{array}$ & $\begin{array}{c}0.000535 \\
(0.0169)\end{array}$ & $\begin{array}{l}-0.00387 \\
(0.0169)\end{array}$ & $\begin{array}{l}0.00388 \\
(0.0156)\end{array}$ & $\begin{array}{l}0.0181^{* * *} \\
(0.00643)\end{array}$ & $\begin{array}{c}0.0602^{* * *} \\
(0.0217)\end{array}$ & $\begin{array}{l}0.0204^{* * *} \\
(0.00527)\end{array}$ & $\begin{array}{c}0.0475^{* * *} \\
(0.0177)\end{array}$ & $\begin{array}{l}0.0203^{* * *} \\
(0.00454)\end{array}$ \\
\hline $\begin{array}{l}\text { Overhead Costs / Total } \\
\text { Assets (\%) }\end{array}$ & + & & & & $\begin{array}{l}0.171^{* *} \\
(0.0682)\end{array}$ & & $\begin{array}{l}0.146 * * \\
(0.0634)\end{array}$ & $\begin{array}{l}0.120^{*} \\
(0.0699)\end{array}$ & $\begin{array}{l}0.145^{* *} \\
(0.0673)\end{array}$ & & & & & \\
\hline $\begin{array}{l}\text { Domestic Bank Deposits / } \\
\text { GDP (\%) }\end{array}$ & - & & & & & $\begin{array}{l}-0.0315^{*} \\
(0.0158)\end{array}$ & $\begin{array}{c}-0.0253^{* * *} \\
(0.00839)\end{array}$ & $\begin{array}{c}-0.0227^{* * *} \\
(0.00754)\end{array}$ & $\begin{array}{c}-0.0246 * * * \\
(0.00637)\end{array}$ & & & & & \\
\hline Infant mortality & + & & & & & & & $\begin{array}{l}0.0260^{* * *} \\
(0.00946)\end{array}$ & & & & & & \\
\hline Population (log) & - & & & & & & & & $\begin{array}{c}-3.484^{* * *} \\
(1.032)\end{array}$ & & & & & \\
\hline Poverty headcount & + & & & & & & & & & & $\begin{array}{l}0.0351^{*} \\
(0.0200)\end{array}$ & & & \\
\hline Rule of law & - & & & & & & & & & & & $\begin{array}{l}-0.851^{*} \\
(0.471)\end{array}$ & & \\
\hline Credit information depth & - & & & & & & & & & & & & $\begin{array}{l}-0.166^{*} \\
(0.0861)\end{array}$ & \\
\hline Population density & - & & & & & & & & & & & & & $\begin{array}{l}-0.00201 * \\
(0.00116)\end{array}$ \\
\hline Trend & & $\begin{array}{l}-0.377 \\
(0.372)\end{array}$ & $\begin{array}{l}-0.416 \\
(0.414)\end{array}$ & $\begin{array}{l}-0.196 \\
(0.265)\end{array}$ & $\begin{array}{l}0.0489 \\
(0.124)\end{array}$ & $\begin{array}{l}-0.168 \\
(0.257)\end{array}$ & $\begin{array}{l}0.0684 \\
(0.110)\end{array}$ & $\begin{array}{l}0.285^{* * *} \\
(0.0728)\end{array}$ & $\begin{array}{c}0.398^{* * *} \\
(0.134)\end{array}$ & $\begin{array}{c}-0.339 * * \\
(0.144)\end{array}$ & $\begin{array}{l}-0.459^{*} \\
(0.256)\end{array}$ & $\begin{array}{c}-0.370^{* *} \\
(0.154)\end{array}$ & $\begin{array}{c}-0.548^{* *} \\
(0.248)\end{array}$ & $\begin{array}{l}-0.347^{* *} \\
(0.149)\end{array}$ \\
\hline Constant & & $\begin{array}{l}2.863 \\
(5.807)\end{array}$ & $\begin{array}{c}1.173 \\
(8.059)\end{array}$ & $\begin{array}{c}4.026 \\
(5.560)\end{array}$ & $\begin{array}{c}1.904 \\
(1.775)\end{array}$ & $\begin{array}{c}2.792 \\
(6.104)\end{array}$ & $\begin{array}{c}1.079 \\
(1.659)\end{array}$ & $\begin{array}{l}-1.085 \\
(1.008)\end{array}$ & $\begin{array}{c}55.44^{* * *} \\
(16.19)\end{array}$ & $\begin{array}{c}1.571 \\
(1.347)\end{array}$ & $\begin{array}{c}1.116 \\
(1.342)\end{array}$ & $\begin{array}{c}2.159 * * * \\
(0.500)\end{array}$ & $\begin{array}{c}3.578^{* * *} \\
(0.928)\end{array}$ & $\begin{array}{c}2.846 * * * \\
(0.755)\end{array}$ \\
\hline Observations & & 119 & 119 & 119 & 106 & 119 & 106 & 106 & 106 & 119 & 64 & 120 & 80 & 120 \\
\hline Number of Ccode & & 41 & 41 & 41 & 38 & 41 & 38 & 38 & 38 & 41 & 39 & 41 & 41 & 41 \\
\hline Frac. group variance & & 0.692 & 0.705 & 0.748 & 0.852 & 0.717 & 0.861 & 0.914 & 0.992 & 0.650 & 0.465 & 0.636 & 0.509 & 0.652 \\
\hline R2 within & & 0.0960 & 0.105 & 0.299 & 0.262 & 0.323 & 0.328 & 0.373 & 0.372 & & & & & \\
\hline R2 between & & 0.00174 & 0.00785 & 0.0140 & 0.00759 & 0.140 & 0.0785 & 0.0517 & 0.0905 & & & & & \\
\hline
\end{tabular}


Table 3. The determinants of private credit and financial development gap in CFA franc zone

\begin{tabular}{|c|c|c|c|c|c|c|}
\hline $\begin{array}{l}\text { VARIABLES } \\
\text { (period average) } \\
\end{array}$ & $\begin{array}{c}\text { (1) } \\
\text { Private } \\
\text { Credit / GDP } \\
(\%) \\
\end{array}$ & $\begin{array}{c}\text { (2) } \\
\text { Private } \\
\text { Credit / GDP } \\
(\%) \\
\end{array}$ & $\begin{array}{c}\text { (3) } \\
\text { Private } \\
\text { Credit / GDP } \\
(\%) \\
\end{array}$ & $\begin{array}{c}\text { Financial } \\
\text { Gap }\end{array}$ & $\begin{array}{l}\text { Financial } \\
\text { Gap }\end{array}$ & $\begin{array}{l}\text { Financial } \\
\text { Gap }\end{array}$ \\
\hline log GDP per capita (lag) & $\begin{array}{l}3.693^{*} \\
(2.060)\end{array}$ & $\begin{array}{l}4.399 * * \\
(1.726)\end{array}$ & $\begin{array}{c}2.720 \\
(1.980)\end{array}$ & $\begin{array}{l}-0.0402 \\
(0.815)\end{array}$ & & \\
\hline $\begin{array}{l}\text { Consumer Prices, \% change } \\
\text { (lag) }\end{array}$ & $\begin{array}{c}-0.0224 * * * \\
(0.00709)\end{array}$ & $\begin{array}{c}-0.0218 * * * \\
(0.00619)\end{array}$ & $\begin{array}{c}-0.0513^{* *} \\
(0.0251)\end{array}$ & $\begin{array}{l}0.0201 * * \\
(0.00832)\end{array}$ & $\begin{array}{l}0.0192 * * \\
(0.00802)\end{array}$ & $\begin{array}{c}0.00759 * * * \\
(0.00108)\end{array}$ \\
\hline $\begin{array}{l}\text { Natural Resource GDP share } \\
\text { (of total GDP) }\end{array}$ & $\begin{array}{l}-0.0968 * \\
(0.0512)\end{array}$ & $\begin{array}{l}-0.0863^{*} \\
(0.0472)\end{array}$ & $\begin{array}{l}-0.0803^{*} \\
(0.0436)\end{array}$ & $\begin{array}{c}0.0289 \\
(0.0193)\end{array}$ & $\begin{array}{l}-0.0167^{*} \\
(0.00983)\end{array}$ & $\begin{array}{c}0.0118 \\
(0.00826)\end{array}$ \\
\hline $\begin{array}{l}\text { CFA* Natural Resource GDP } \\
\text { share }\end{array}$ & $\begin{array}{c}-0.102 \\
(0.0884)\end{array}$ & $\begin{array}{c}-0.00486 \\
(0.116)\end{array}$ & $\begin{array}{l}0.00128 \\
(0.0818)\end{array}$ & & $\begin{array}{l}0.104^{* *} \\
(0.0395)\end{array}$ & \\
\hline $\begin{array}{l}\text { CFA*Government } \\
\text { Effectiveness }\end{array}$ & & $\begin{array}{l}10.40 * \\
(5.873)\end{array}$ & $\begin{array}{c}8.849 \\
(5.575)\end{array}$ & & & \\
\hline CFA*Property Rights & & & $\begin{array}{c}0.140^{*} \\
(0.0779)\end{array}$ & & & \\
\hline CFA*Operational Costs & & & & & & $\begin{array}{l}0.246 * \\
(0.136)\end{array}$ \\
\hline Trend & $\begin{array}{c}2.292^{* *} \\
(0.944)\end{array}$ & $\begin{array}{c}2.187^{* *} \\
(0.920)\end{array}$ & $\begin{array}{c}3.131 * * * \\
(0.889)\end{array}$ & $\begin{array}{c}-0.248 \\
(0.244)\end{array}$ & $\begin{array}{c}-0.350 * * \\
(0.153)\end{array}$ & $\begin{array}{l}-0.0512 \\
(0.0682)\end{array}$ \\
\hline Constant & $\begin{array}{c}-12.11 \\
(11.41)\end{array}$ & $\begin{array}{l}-13.37 \\
(9.512)\end{array}$ & $\begin{array}{l}-7.115 \\
(11.06)\end{array}$ & $\begin{array}{c}2.446 \\
(4.583)\end{array}$ & $\begin{array}{c}2.365^{* * *} \\
(0.442)\end{array}$ & $\begin{array}{c}1.145^{* * *} \\
(0.335)\end{array}$ \\
\hline Observations & 119 & 119 & 106 & 119 & 120 & 106 \\
\hline Number of countries & 41 & 41 & 41 & 41 & 41 & 38 \\
\hline Frac. group variance & 0.886 & 0.883 & 0.931 & 0.688 & 0.639 & 0.858 \\
\hline R2 within & 0.432 & 0.445 & 0.590 & 0.307 & 0.326 & 0.264 \\
\hline $\mathrm{R} 2$ between & 0.436 & 0.324 & 0.288 & 0.227 & 0.430 & 0.0565 \\
\hline
\end{tabular}

Note: Robust standard errors in parentheses $* * * p<0.01, * * p<0.05, * p<0.1$; country fixed effects in all regressions 
Table 4. Summary statistics (4 year averages, 1997-2012)

\begin{tabular}{|c|c|c|c|c|c|c|c|c|}
\hline Variable & No obs & Mean & Standard dev. & Median & Min & Max & Skewness & Kurtosis \\
\hline Private credit (\% GDP) & 164 & 17.07 & 16.39 & 12.65 & 0.81 & 90.68 & 2.18 & 8.01 \\
\hline Financial Gap** & 163 & 1.95 & 1.86 & 1.28 & 0.28 & 11.42 & 2.70 & 11.65 \\
\hline GDP per cap. (log) & 167 & 6.63 & 1.13 & 6.26 & 4.79 & 9.82 & 0.91 & 2.93 \\
\hline Inflation (\%) & 168 & 11.57 & 28.39 & 6.18 & 0.37 & 265.76 & 7.24 & 59.29 \\
\hline Natural Resources (\% GDP) & 168 & 7.64 & 17.01 & 0.00 & 0.00 & 85.22 & 2.80 & 10.54 \\
\hline Debt to GDP (\%) & 158 & 74 & 91 & 49 & 1 & 692 & 4.23 & 25.96 \\
\hline Domestic debt to GDP (\%) & 123 & 20.64 & 24.27 & 14.38 & 0.24 & 137.83 & 2.65 & 10.80 \\
\hline Government effectiveness (index) & 126 & -0.72 & 0.60 & -0.71 & -1.71 & 0.85 & 0.54 & 2.85 \\
\hline Rule of law (index) & 126 & -0.66 & 0.62 & -0.64 & -1.72 & 1.03 & 0.47 & 2.72 \\
\hline Political stability (index) & 168 & -0.45 & 0.89 & -0.25 & -2.79 & 1.09 & -0.38 & 2.40 \\
\hline Credit register coverage* (\% adults) & 84 & 6.79 & 14.99 & 0.93 & 0.00 & 59.33 & 2.51 & 7.92 \\
\hline Depth credit info* (index) & 84 & 1.52 & 1.56 & 1.00 & 0.00 & 6.00 & 0.90 & 2.90 \\
\hline Property Rights* (\%) & 82 & 2.04 & 5.46 & 0.06 & 0.00 & 39.25 & 4.90 & 30.18 \\
\hline Deposits (\% GDP) & 164 & 25.93 & 22.99 & 18.90 & 1.99 & 120.50 & 1.93 & 6.61 \\
\hline Branches* (per 100,000 adults) & 100 & 4.02 & 4.95 & 2.38 & 0.13 & 29.81 & 2.80 & 12.02 \\
\hline Non-interest income (\% total income) & 137 & 40.89 & 14.92 & 40.84 & 0.00 & 82.87 & -0.15 & 3.66 \\
\hline Operational costs (\% assets) & 143 & 5.30 & 2.41 & 5.08 & 0.02 & 15.99 & 0.83 & 5.46 \\
\hline Interest rate spread (\%) & 163 & 8.79 & 8.56 & 6.27 & 2.06 & 68.75 & 3.91 & 23.30 \\
\hline Cost-income ratio (\%) & 146 & 58.81 & 17.38 & 59.27 & 4.30 & 118.30 & 0.44 & 4.72 \\
\hline Return on Equity (ROE) & 146 & 21.73 & 20.09 & 18.86 & -92.29 & 129.50 & 0.15 & 14.41 \\
\hline Population (log) & 168 & 15.54 & 1.59 & 15.96 & 11.28 & 18.89 & -0.56 & 3.04 \\
\hline Population Density & 168 & 90.74 & 118.94 & 51.00 & 2.22 & 632.16 & 2.60 & 10.37 \\
\hline Urban population (\%) & 168 & 37.01 & 15.77 & 37.38 & 7.94 & 85.95 & 0.45 & 3.06 \\
\hline Infant mortality (per 100,000 infants) & 168 & 73.34 & 27.99 & 72.94 & 11.55 & 144.80 & -0.07 & 2.72 \\
\hline Power consumption (per capita, KWH, log)* & 73 & 5.51 & 1.22 & 5.11 & 3.84 & 8.47 & 0.81 & 2.80 \\
\hline Mobile Subscriptions (per 100 adults) & 168 & 22.71 & 29.42 & 9.30 & 0.00 & 134.20 & 1.68 & 5.56 \\
\hline Internet Use (\%) & 168 & 3.94 & 6.90 & 1.14 & 0.00 & 43.75 & 3.08 & 13.75 \\
\hline Poverty Headcount* (\% population) & 71 & 48.60 & 14.41 & 48.40 & 13.40 & 76.80 & -0.13 & 2.47 \\
\hline CFA Gov Effectiveness*** & 126 & -0.33 & 0.52 & 0.00 & -1.67 & 0.00 & -1.25 & 3.05 \\
\hline CFA Rule of Law*** & 126 & -0.31 & 0.51 & 0.00 & -1.60 & 0.00 & -1.34 & 3.18 \\
\hline CFA Property Rights*** & 146 & 12.21 & 17.55 & 0.00 & 0.00 & 65.00 & 1.08 & 2.85 \\
\hline CFA Operational costs $* * *$ & 143 & 1.82 & 2.98 & 0.00 & 0.00 & 15.99 & 1.84 & 6.95 \\
\hline CFA Deposits*** & 164 & 4.73 & 7.90 & 0.00 & 0.00 & 35.84 & 1.64 & 4.92 \\
\hline CFA Political Stability*** & 168 & 0.18 & 0.48 & 0.00 & -0.69 & 2.00 & 2.13 & 7.13 \\
\hline
\end{tabular}

$*$ refers to variables with less than 3 observations per country

** refers to Financial Development Gap (as explained in section C)

$* * *$ refers to interaction variables 
Table 5. Financial Inclusion in sub-Saharan Africa (2012)

\begin{tabular}{|c|c|c|c|c|c|}
\hline \multirow{2}{*}{$\begin{array}{r}\text { Country } \\
\text { or } \\
\text { region }\end{array}$} & \multicolumn{5}{|c|}{$\begin{array}{l}\text { Share of adults with an account at any } \\
\text { kind of formal financial institution }\end{array}$} \\
\hline & Overall & $\begin{array}{c}\text { poorest } \\
20 \%\end{array}$ & $\begin{array}{l}\text { richest } \\
20 \%\end{array}$ & $\begin{array}{c}\text { women } \\
\text { only }\end{array}$ & $\begin{array}{l}\text { men } \\
\text { only }\end{array}$ \\
\hline Angola & 39.2 & 31.4 & 39.9 & 38.9 & 39.5 \\
\hline Benin & 10.5 & 4.9 & 24.0 & 9.8 & 11.2 \\
\hline Botswana & 30.3 & 12.1 & 47.9 & 28.4 & 32.2 \\
\hline Burkina Faso & 13.4 & 6.4 & 25.5 & 10.8 & 15.7 \\
\hline Burundi & 7.2 & 2.6 & 22.9 & 5.9 & 8.6 \\
\hline Cameroon & 14.8 & 6.1 & 22.5 & 10.9 & 18.8 \\
\hline Central African Rep. & 3.3 & 0.7 & 9.3 & 3.4 & 3.2 \\
\hline Chad & 9.0 & 5.6 & 26.2 & 6.8 & 11.5 \\
\hline Comoros & 21.7 & 9.3 & 39.6 & 17.9 & 25.7 \\
\hline Congo, Dem. Rep. & 3.7 & 0.2 & 17.8 & 2.8 & 4.7 \\
\hline Congo, Rep. & 9.0 & 1.1 & 20.0 & 6.8 & 11.3 \\
\hline Gabon & 18.9 & 3.7 & 37.5 & 17.2 & 20.8 \\
\hline Ghana & 29.4 & 17.3 & 60.9 & 27.1 & 31.8 \\
\hline Guinea & 3.7 & 1.6 & 10.0 & 2.9 & 4.4 \\
\hline Kenya & 42.3 & 18.7 & 85.0 & 39.2 & 45.6 \\
\hline Lesotho & 18.5 & 8.0 & 29.5 & 16.9 & 20.2 \\
\hline Liberia & 18.8 & 2.8 & 41.2 & 14.7 & 23.0 \\
\hline Madagascar & 5.5 & 1.4 & 19.2 & 4.6 & 6.5 \\
\hline Malawi & 16.5 & 8.6 & 36.1 & 16.9 & 16.2 \\
\hline Mali & 8.2 & 3.5 & 17.6 & 6.9 & 9.6 \\
\hline Mauritania & 17.5 & 7.3 & 43.1 & 12.1 & 23.3 \\
\hline Mauritius & 80.1 & 66.0 & 93.9 & 74.7 & 85.8 \\
\hline Mozambique & 39.9 & 20.5 & 56.4 & 35.5 & 45.0 \\
\hline Niger & 1.5 & 0.0 & 5.9 & 1.5 & 1.6 \\
\hline Nigeria & 29.7 & 12.0 & 62.3 & 26.0 & 33.3 \\
\hline Rwanda & 32.8 & 23.1 & 42.2 & 28.2 & 37.5 \\
\hline Senegal & 5.8 & 3.8 & 12.6 & 5.5 & 6.2 \\
\hline Sierra Leone & 15.3 & 4.4 & 30.4 & 12.8 & 18.0 \\
\hline Somalia & 31.0 & 11.5 & 58.1 & 27.3 & 34.6 \\
\hline South Africa & 53.6 & 34.8 & 78.0 & 51.0 & 56.4 \\
\hline Sudan & 6.9 & 4.3 & 15.2 & 4.4 & 9.4 \\
\hline Swaziland & 28.6 & 11.8 & 44.3 & 27.4 & 29.7 \\
\hline Tanzania & 17.3 & 2.7 & 45.4 & 13.8 & 20.8 \\
\hline Togo & 10.2 & 1.5 & 17.9 & 9.2 & 11.2 \\
\hline Uganda & 20.5 & 7.2 & 36.7 & 15.1 & 25.8 \\
\hline Zambia & 21.4 & 7.6 & 50.3 & 23.3 & 19.4 \\
\hline Zimbabwe & 39.7 & 21.7 & 62.7 & 37.1 & 42.5 \\
\hline SSA (simple average) & 21.0 & 11.0 & 36.8 & 19.3 & 22.8 \\
\hline SSA (weighted average) & 24.2 & 11.6 & 46.2 & 21.7 & 26.9 \\
\hline $\operatorname{CEMAC~(w/o~GNQ)~}$ & 11.6 & 4.8 & 22.4 & 8.8 & 14.5 \\
\hline WAEMU (w/o CIV) & 7.4 & 3.2 & 16.0 & 6.4 & 8.4 \\
\hline Frontier Economies & 32.3 & 15.6 & 61.0 & 28.9 & 35.7 \\
\hline
\end{tabular}
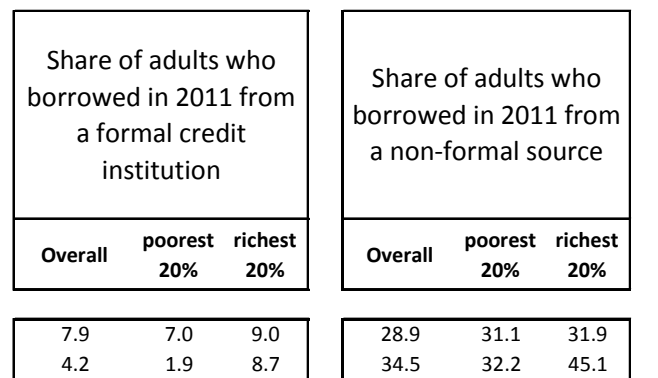

\begin{tabular}{|ccc|}
\hline 26.7 & 29.7 & 28.2 \\
21.5 & 22.3 & 28.1 \\
7.4 & 3.4 & 15.7 \\
29.9 & 18.0 & 35.2 \\
35.2 & 37.0 & 33.2 \\
30.4 & 29.7 & 38.7 \\
18.9
\end{tabular}

$\begin{array}{lll}30.4 & 29.7 & 38.7\end{array}$

$\begin{array}{lll}18.3 & 12.3 & 24.1 \\ 32.5 & 38.4 & 35.9\end{array}$

$\begin{array}{lll}32.5 & 38.4 & 35.9\end{array}$

$\begin{array}{lll}34.7 & 31.5 & 40.3 \\ 29.7 & 21.7 & 34.9 \\ 24.6 & 24.8 & 15.1\end{array}$

$\begin{array}{lll}29.7 & 21.7 & 34.9 \\ 24.6 & 24.8 & 15.1\end{array}$

$\begin{array}{lll}24.6 & 24.8 & 15.1 \\ 22.5 & 20.8 & 20.8 \\ 16.5 & 17.1\end{array}$

$\begin{array}{lll}22.5 & 20.8 & 20.8 \\ 16.5 & 17.1 & 14.2 \\ 34.4 & 39.2 & 35.8\end{array}$

$\begin{array}{lll}16.5 & 17.1 & 14.2 \\ 34.4 & 39.2 & 35.8 \\ 19.2 & 9.5 & 33.9\end{array}$

$\begin{array}{ccc}34.4 & 39.2 & 35.8 \\ 19.2 & 9.5 & 33.9\end{array}$

$\begin{array}{lll}19.2 & 9.5 & 33.9 \\ 24.3 & 21.9 & 28.4 \\ 2.6 & 15.2 & 32.2\end{array}$

\begin{tabular}{lll}
22.3 & 21.9 & 28.4 \\
22.6 & 15.2 & 32.2 \\
\hline & 47.1 & 33.0
\end{tabular}

$\begin{array}{lll}40.8 & 47.1 & 33.0\end{array}$

$\begin{array}{lll}27.2 & 25.5 & 25.6 \\ 22.5 & 17.6 & 36.2 \\ 36.4 & 29.7 & 44.4 \\ 16.3 & 9.9 & 26.8\end{array}$

$\begin{array}{lll}36.4 & 29.7 & 44.4 \\ 16.3 & 9.9 & 26.8\end{array}$

$\begin{array}{ccc}16.3 & 9.9 & 26.8 \\ 25.1 & 23.9 & 19.1 \\ 319 & 28.6 & 35.5\end{array}$

$\begin{array}{lll}31.9 & 28.6 & 35.5 \\ 1.9 & \end{array}$

$\begin{array}{lll}13.8 & 10.6 & 9.4 \\ 28.5 & 24.7 & 26.7\end{array}$

$\begin{array}{lll}13.8 & 24.7 & 26.7 \\ 15.8 & 16.9 & 20.7\end{array}$

$\begin{array}{lll}15.5 & 12.1 & 18.9\end{array}$

$\begin{array}{lll}15.5 & 24.2 & 42.9 \\ 16.3 & 11.6 & 29.2\end{array}$

$\begin{array}{lll}47.9 & 11.6 & 29.2 \\ 41.1 & 32.9\end{array}$

$\begin{array}{lll}25.2 & 15.8 & 31.7 \\ 33.8 & 28.7 & 26.9\end{array}$

$\begin{array}{ccc}18.0 & 15.7 & 21.4 \\ 5.5 & 2.5 & 11.0 \\ 17.4 & 14.8 & 17.3\end{array}$

$\begin{array}{lll}4.5 & 4.9 & 8.2\end{array}$

$\begin{array}{lll}0.9 & 0.0 & 3.7 \\ 6.2 & 3.8 & 10.3 \\ 7.2 & 2.2 & 16.8\end{array}$

$\begin{array}{lll}6.2 & 3.8 & 10.3 \\ 7.2 & 2.2 & 16.8 \\ 1.5 & 0.6 & 6.5\end{array}$

$\begin{array}{lll}1.5 & 0.6 & 6.5\end{array}$

$\begin{array}{lll}2.8 & 0.6 & 7.5 \\ 2.3 & 0.0 & 7.4\end{array}$

$\begin{array}{lll}5.8 & 4.6 & 12.6\end{array}$

$\begin{array}{lll}2.8 & 4.6 & 12.6 \\ 2.4 & 1.0 & 7.7 \\ 9.7 & 1.7 & 21.3\end{array}$

$\begin{array}{lll}9.7 & 1.7 & 21.3 \\ 3.0 & 0.0 & 6.0\end{array}$

$\begin{array}{lll}3.0 & 0.0 & 6.0 \\ 6.5 & 0.6 & 16.2\end{array}$

$\begin{array}{lll}6.5 & 0.6 & 16.2 \\ 2.3 & 0.5 & 5.5\end{array}$

$\begin{array}{ccc}2.3 & 0.5 & 5.5 \\ 9.2 & 8.5 & 12.9 \\ 3.7 & 1.8 & 8.5 \\ 7.9 & 3.2 & 13.9\end{array}$

$\begin{array}{ccc}3.7 & 1.8 & 8.5 \\ 7.9 & 3.2 & 13.9 \\ 14.3 & 6.8 & 29.1\end{array}$

$\begin{array}{ccc}14.3 & 6.8 & 29.1 \\ 5.9 & 2.1 & 10.5 \\ 1.3 & 0.4 & 3.7\end{array}$

$\begin{array}{lll}5.9 & 2.1 & 10.5 \\ 1.3 & 0.4 & 3.7\end{array}$

$\begin{array}{lll}2.1 & 1.2 & 1.5\end{array}$

$\begin{array}{ccc}8.4 & 2.3 & 13.8 \\ 3.5 & 3.5 & 6.1 \\ 6.5 & 3.2 & 10.0\end{array}$

$\begin{array}{ccc}6.1 & 3.2 & 10.0 \\ 1.6 & 1.5 & 2.2\end{array}$

$\begin{array}{lll}1.6 & 1.5 & 2.2 \\ 8.9 & 5.6 & 25.3 \\ 1.8 & 1.8 & 3.2\end{array}$

$\begin{array}{ccc}1.8 & 1.8 & 3.2 \\ 11.5 & 3.1 & 22.0 \\ 6.8 & 0.8 & 1.9\end{array}$

$\begin{array}{ccc}11.5 & 3.1 & 22.0 \\ 6.6 & 0.8 & 14.9 \\ 3.8 & 0.0 & 6.4\end{array}$

$\begin{array}{ccc}6.8 & 0.0 & 6.4 \\ 8.9 & 5.0 & 14.6 \\ 6.1 & 1.5 & 11.9 \\ 4.9 & 3.8 & 9.5\end{array}$

$\begin{array}{ccc}6.1 & 1.5 & 11.9 \\ 4.9 & 3.8 & 9.5\end{array}$

\begin{tabular}{|lll|}
\hline 28.9 & 31.1 & 31.9 \\
34.5 & 32.2 & 45.1 \\
49.2 & 41.5 & 52.1 \\
33.9 & 23.2 & 34.2 \\
51.5 & 53.6 & 46.7 \\
47.9 & 54.9 & 48.1 \\
24.8 & 20.3 & 23.7 \\
38.9 & 45.1 & 38.7 \\
32.0 & 28.6 & 36.1 \\
32.8 & 30.3 & 41.2 \\
29.7 & 26.0 & 24.9 \\
30.5 & 27.1 & 31.6 \\
32.1 & 38.3 & 21.9 \\
43.2 & 47.1 & 36.1 \\
65.7 & 51.3 & 78.4 \\
54.9 & 51.1 & 61.2 \\
47.8 & 51.9 & 51.2 \\
62.3 & 64.0 & 50.4 \\
47.1 & 45.0 & 42.6 \\
26.6 & 23.2 & 38.8 \\
42.0 & 35.6 & 52.6 \\
19.0 & 16.3 & 27.0 \\
37.7 & 40.8 & 33.7 \\
47.1 & 36.9 & 52.8 \\
47.3 & 38.6 & 49.3 \\
32.6 & 35.6 & 32.2 \\
28.5 & 28.3 & 37.8 \\
46.4 & 43.1 & 52.3 \\
36.2 & 28.6 & 41.1 \\
41.9 & 38.4 & 50.3 \\
64.5 & 66.3 & 57.2 \\
59.4 & 55.6 & 55.1 \\
49.5 & 42.8 & 45.1 \\
21.4 & 20.3 & 24.7 \\
50.2 & 48.0 & 58.9 \\
44.4 & 47.7 & 46.5 \\
61.6 & 52.8 & 75.7 \\
\hline & & \\
\hline
\end{tabular}

Share of adults who use

of mobile banking

$\begin{array}{ccc}\text { Overall } & \text { poorest } & \text { richest } \\ 20 \% & 20 \%\end{array}$

\begin{tabular}{|ccc|}
\hline 25.5 & 24.9 & 30.1 \\
0.4 & 0.0 & 1.4 \\
9.1 & 1.5 & 20.6
\end{tabular}

$\begin{array}{ccc}0.4 & 0.0 & 1.4 \\ 9.1 & 1.5 & 20.6 \\ 0.7 & 0.9 & 0.4\end{array}$

$\begin{array}{lll}0.7 & 0.9 & 0.4 \\ 5.2 & 2.5 & 14.7\end{array}$

$\begin{array}{ccc}0.7 & 0.9 & 0.4 \\ 10.2 & 2.5 & 14.7 \\ 10.9 & 5.7 & 18.8\end{array}$

$\begin{array}{lll}1.9 & 0.0 & 6.5\end{array}$

$\begin{array}{ccc}18.2 & 23.3 & 14.5 \\ 3.7 & 1.1 & 7.5\end{array}$

$\begin{array}{lll}3.7 & 1.1 & 7.5 \\ 2.2 & 0.2 & 6.9\end{array}$

$\begin{array}{ccc}2.2 & 0.2 & 6.9 \\ 37.2 & 32.3 & 44.5 \\ 50.1 & 47.0 & 60.9\end{array}$

$\begin{array}{lll}37.2 & 32.3 & 44.5 \\ 50.1 & 47.0 & 60.9\end{array}$

$\begin{array}{lll}1.9 & 3.1 & 3.9 \\ 6.8 & 2.5 & 11.7\end{array}$

$\begin{array}{ccc}6.8 & 2.5 & 11.7 \\ 68.2 & 46.4 & 92.8\end{array}$

$\begin{array}{ccc}6.8 & 2.5 & 11.7 \\ 7.2 & 46.4 & 92.8 \\ 7.2 & 6.4 & 7.4\end{array}$

$\begin{array}{lll}7.2 & 6.4 & 7.4 \\ 18.8 & 10.5 & 24.5\end{array}$

$\begin{array}{lll}1.2 & 0.0 & 5.6 \\ 1.0 & 1.1 & 1.6\end{array}$

$\begin{array}{lll}1.0 & 1.1 & 1.6 \\ 1.4 & 0.9 & 3.1 \\ 18.7 & 13.1 & 29.8\end{array}$

$\begin{array}{ccc}18.7 & 13.1 & 29.8 \\ 9.3 & 5.3 & 17.6\end{array}$

$\begin{array}{ccc}9.3 & 5.3 & 17.6 \\ 2.5 & 1.4 & 5.8 \\ 2.8 & 3.4 & 4.3\end{array}$

$\begin{array}{lll}2.5 & 1.4 & 5.8 \\ 2.8 & 3.4 & 4.3\end{array}$

$\begin{array}{lll}12.9 & 3.7 & 22.0\end{array}$

$\begin{array}{lll}3.9 & 1.0 & 8.1 \\ 1.1 & 0.6 & 1.6\end{array}$

$\begin{array}{lll}2.2 & 0.2 & 5.2\end{array}$

$\begin{array}{lll}33.9 & 11.0 & 66.9 \\ 11.1 & 6.0 & 34.5\end{array}$

$\begin{array}{ccc}11.1 & 6.0 & 34.5 \\ 51.7 & 44.9 & 59.5\end{array}$

$\begin{array}{ccc}11.1 & 6.0 & 34.5 \\ 20.3 & 5.9 & 59.5 \\ 23.4 & 5.1 & 40.2\end{array}$

$\begin{array}{ccc}23.4 & 5.1 & 38.4 \\ 1.4 & 0.0 & 4.5\end{array}$

$\begin{array}{ccc}1.4 & 0.0 & 4.5 \\ 27.3 & 16.0 & 40.7 \\ 5.0 & 2.0 & 15.4\end{array}$

\begin{tabular}{ccc}
1.4 & 0.0 & 4.5 \\
5.0 & 2.0 & 15.4 \\
3.6 & 2.2 & 7.4 \\
\hline
\end{tabular}

Source: Global Findex (2011) and our calculations

\begin{tabular}{|ccc|}
\hline 5.2 & 2.6 & 10.4 \\
4.8 & 2.4 & 9.7 \\
4.3 & 3.5 & 8.1 \\
3.0 & 1.5 & 6.6 \\
5.5 & 2.6 & 11.2
\end{tabular}$\quad\left[\begin{array}{lll|}41.7 & 38.8 & 43.8 \\
44.3 & 40.4 & 47.1 \\
40.6 & 44.6 & 40.0 \\
34.5 & 30.4 & 39.5 \\
47.3 & 41.0 & 51.0 \\
\hline\end{array}\right.$

\begin{tabular}{|ccc|}
\hline 13.6 & 8.7 & 20.7 \\
14.5 & 8.0 & 24.0 \\
15.6 & 13.9 & 20.6 \\
2.1 & 1.3 & 3.6 \\
19.1 & 9.4 & 31.8 \\
\hline
\end{tabular}

CInternational Monetary Fund. Not for Redistribution 
Table 6. Correlation matrix (1997-2012, 4 year averages, non-overlapping periods)

\begin{tabular}{|c|c|c|c|c|c|c|c|c|c|c|c|c|c|c|c|c|c|c|c|c|c|c|c|c|c|c|c|c|c|c|c|c|}
\hline & 1 & 2 & 3 & 4 & 5 & 6 & 7 & 8 & 9 & 10 & 11 & 12 & 13 & 14 & 15 & 16 & 17 & 18 & 19 & 20 & 21 & 22 & 23 & 24 & 25 & 26 & 27 & 28 & 29 & 30 & 31 & 32 \\
\hline 1 Private Credit to GDP & 1.00 & & & & & & & & & & & & & & & & & & & & & & & & & & & & & & & \\
\hline 2 Financial Gap & -0.95 & 1.00 & & & & & & & & & & & & & & & & & & & & & & & & & & & & & & \\
\hline 3 Deposits & 0.93 & -0.53 & 1.00 & & & & & & & & & & & & & & & & & & & & & & & & & & & & & \\
\hline 4 Branches & 0.85 & -0.43 & 0.93 & 1.00 & & & & & & & & & & & & & & & & & & & & & & & & & & & & \\
\hline 5 Non-interest Income & -0.04 & 0.16 & -0.07 & -0.10 & 1.00 & & & & & & & & & & & & & & & & & & & & & & & & & & & \\
\hline 6 GDPcapita & 0.66 & 0.05 & 0.70 & 0.79 & 0.08 & 1.00 & & & & & & & & & & & & & & & & & & & & & & & & & & \\
\hline 7 GDP per capita (log) & 0.48 & 0.17 & 0.54 & 0.67 & 0.19 & 0.94 & 1.00 & & & & & & & & & & & & & & & & & & & & & & & & & \\
\hline 8 Inflation & -0.16 & -0.04 & -0.11 & 0.03 & -0.63 & -0.15 & -0.26 & 1.00 & & & & & & & & & & & & & & & & & & & & & & & & \\
\hline 9 Natural Resource GDP & -0.33 & 0.74 & -0.22 & -0.09 & 0.30 & 0.40 & 0.56 & -0.09 & 1.00 & & & & & & & & & & & & & & & & & & & & & & & \\
\hline 10 Real GDP growth & -0.16 & 0.06 & 0.02 & 0.19 & -0.19 & 0.16 & 0.21 & 0.64 & 0.44 & 1.00 & & & & & & & & & & & & & & & & & & & & & & \\
\hline 11 Debt-to-GDP & -0.44 & 0.49 & -0.57 & -0.59 & 0.40 & -0.46 & -0.47 & 0.01 & 0.07 & -0.24 & 1.00 & & & & & & & & & & & & & & & & & & & & & \\
\hline 12 Domestic Debt-to-GDP & 0.50 & -0.54 & 0.50 & 0.39 & -0.02 & -0.03 & -0.16 & -0.16 & -0.45 & -0.10 & -0.23 & 1.00 & & & & & & & & & & & & & & & & & & & & \\
\hline 13 Gov Effectiveness & 0.80 & -0.46 & 0.77 & 0.78 & -0.37 & 0.52 & 0.46 & -0.05 & -0.34 & -0.08 & -0.71 & 0.42 & 1.00 & & & & & & & & & & & & & & & & & & & \\
\hline 14 CFA Gov Effectiveness & 0.39 & -0.39 & 0.46 & 0.48 & -0.81 & 0.15 & 0.00 & 0.70 & -0.34 & 0.45 & -0.52 & 0.27 & 0.56 & 1.00 & & & & & & & & & & & & & & & & & & \\
\hline 15 Rule of Law & 0.76 & -0.46 & 0.77 & 0.77 & -0.30 & 0.46 & 0.35 & -0.06 & -0.37 & -0.15 & -0.63 & 0.49 & 0.92 & 0.48 & 1.00 & & & & & & & & & & & & & & & & & \\
\hline 16 CFA Rule of Law & 0.42 & -0.41 & 0.51 & 0.52 & -0.70 & 0.13 & -0.06 & 0.72 & -0.35 & 0.46 & -0.42 & 0.39 & 0.51 & 0.95 & 0.52 & 1.00 & & & & & & & & & & & & & & & & \\
\hline 17 Political Stability & 0.45 & -0.31 & 0.58 & 0.57 & -0.15 & 0.39 & 0.38 & -0.21 & -0.05 & 0.05 & -0.76 & 0.45 & 0.68 & 0.28 & 0.80 & 0.32 & 1.00 & & & & & & & & & & & & & & & \\
\hline 18 Registry Coverage & -0.15 & -0.30 & -0.16 & -0.21 & 0.27 & -0.35 & -0.30 & -0.26 & -0.20 & 0.06 & -0.04 & 0.37 & -0.18 & -0.22 & -0.14 & -0.20 & 0.15 & 1.00 & & & & & & & & & & & & & & \\
\hline 19 Legal Registry & 0.54 & -0.36 & 0.58 & 0.53 & -0.36 & 0.26 & 0.20 & 0.17 & -0.29 & -0.07 & -0.37 & 0.16 & 0.65 & 0.54 & 0.57 & 0.55 & 0.20 & -0.54 & 1.00 & & & & & & & & & & & & & \\
\hline 20 Depth Credit Info & 0.74 & -0.19 & 0.80 & 0.75 & 0.12 & 0.74 & 0.65 & -0.25 & 0.17 & 0.19 & -0.43 & 0.48 & 0.51 & 0.26 & 0.42 & 0.25 & 0.44 & -0.04 & 0.18 & 1.00 & & & & & & & & & & & & \\
\hline 21 Operational costs & -0.36 & 0.66 & -0.30 & -0.18 & 0.27 & 0.03 & 0.25 & -0.30 & 0.61 & -0.05 & 0.30 & -0.24 & -0.16 & -0.45 & -0.12 & -0.42 & -0.02 & -0.25 & -0.04 & -0.12 & 1.00 & & & & & & & & & & & \\
\hline 22 Interest rate & -0.08 & 0.06 & -0.16 & -0.13 & -0.63 & -0.21 & -0.42 & 0.77 & -0.24 & 0.23 & 0.24 & -0.01 & -0.14 & 0.54 & -0.13 & 0.54 & -0.34 & -0.26 & -0.07 & -0.16 & -0.39 & 1.00 & & & & & & & & & & \\
\hline 23 Cost-Income ratio & -0.36 & 0.83 & -0.45 & -0.45 & 0.21 & -0.08 & -0.07 & -0.15 & 0.45 & -0.26 & 0.71 & -0.34 & -0.48 & -0.48 & -0.37 & -0.43 & -0.37 & -0.17 & -0.33 & -0.27 & 0.60 & 0.10 & 1.00 & & & & & & & & & \\
\hline 24 Return on Assets & 0.14 & -0.62 & 0.25 & 0.40 & -0.47 & -0.10 & -0.17 & 0.58 & -0.45 & 0.36 & -0.35 & 0.33 & 0.32 & 0.63 & 0.33 & 0.66 & 0.14 & -0.08 & 0.36 & 0.01 & -0.32 & 0.34 & -0.67 & 1.00 & & & & & & & & \\
\hline 25 Return on Equity & 0.23 & -0.70 & 0.28 & 0.40 & -0.38 & 0.00 & -0.08 & 0.52 & -0.40 & 0.37 & -0.41 & 0.32 & 0.32 & 0.55 & 0.29 & 0.58 & 0.13 & -0.03 & 0.26 & 0.08 & -0.47 & 0.33 & -0.76 & 0.92 & 1.00 & & & & & & & \\
\hline 26 Population Density & -0.03 & -0.44 & -0.16 & -0.15 & 0.17 & -0.55 & -0.52 & -0.04 & -0.61 & -0.32 & 0.19 & 0.34 & 0.08 & -0.14 & 0.17 & -0.02 & -0.02 & 0.33 & 0.13 & -0.48 & -0.07 & -0.16 & -0.21 & 0.30 & 0.28 & 1.00 & & & & & & \\
\hline 27 Urban Population & 0.01 & 0.48 & -0.08 & 0.12 & 0.38 & 0.56 & 0.71 & -0.30 & 0.70 & 0.16 & -0.06 & -0.31 & 0.02 & -0.41 & -0.09 & -0.48 & 0.05 & -0.06 & -0.37 & 0.26 & 0.41 & -0.30 & 0.23 & -0.39 & -0.20 & -0.33 & 1.00 & & & & & \\
\hline 28 Infant Mortality & -0.58 & 0.27 & -0.62 & -0.51 & 0.10 & -0.35 & -0.33 & 0.36 & 0.23 & 0.44 & 0.46 & -0.24 & -0.72 & -0.14 & -0.81 & -0.18 & -0.67 & 0.34 & -0.66 & -0.25 & -0.16 & 0.42 & 0.14 & -0.02 & 0.05 & -0.12 & 0.14 & 1.00 & & & & \\
\hline 29 Power consumption & 0.92 & -0.25 & 0.77 & 0.74 & 0.01 & 0.73 & 0.57 & -0.10 & -0.12 & -0.08 & -0.32 & 0.32 & 0.70 & 0.30 & 0.60 & 0.30 & 0.31 & -0.26 & 0.36 & 0.71 & -0.29 & 0.04 & -0.21 & -0.02 & 0.16 & -0.16 & 0.30 & -0.39 & 1.00 & & & \\
\hline 30 Mobile Subscriptions & 0.60 & -0.10 & 0.66 & 0.65 & -0.04 & 0.81 & 0.75 & -0.26 & 0.26 & -0.11 & -0.50 & -0.02 & 0.53 & 0.09 & 0.54 & 0.08 & 0.47 & -0.44 & 0.39 & 0.55 & 0.12 & -0.27 & -0.06 & -0.08 & 0.04 & -0.44 & 0.34 & -0.64 & 0.59 & 1.00 & & \\
\hline 31 Internet Use & 0.76 & -0.28 & 0.87 & 0.84 & -0.12 & 0.75 & 0.66 & -0.19 & 0.02 & -0.06 & -0.58 & 0.29 & 0.70 & 0.35 & 0.68 & 0.36 & 0.52 & -0.43 & 0.69 & 0.71 & -0.01 & -0.26 & -0.29 & 0.18 & 0.14 & -0.32 & 0.01 & -0.71 & 0.60 & 0.79 & 1.00 & \\
\hline 32 Poverty Headcount & -0.52 & 0.33 & -0.54 & -0.60 & 0.20 & -0.52 & -0.60 & 0.06 & 0.04 & -0.13 & 0.76 & 0.04 & -0.79 & -0.36 & -0.67 & -0.25 & -0.60 & 0.08 & -0.49 & -0.29 & 0.06 & 0.41 & 0.49 & -0.14 & -0.20 & -0.02 & -0.26 & 0.57 & -0.48 & -0.52 & -0.50 & 1.00 \\
\hline
\end{tabular}


Table 7. Correlation matrix: financial inclusion, depth, and development (2012)

\begin{tabular}{lccc}
\hline \multicolumn{1}{c}{2012} & $\begin{array}{c}\text { Financial } \\
\text { Account } \\
\text { access } \\
\text { (\% adults) }\end{array}$ & $\begin{array}{c}\text { Private } \\
\text { credit to } \\
\text { GDP }\end{array}$ & $\begin{array}{c}\text { Branches } \\
\text { per } \\
100,000 \\
\mathrm{~km} 2\end{array}$ \\
\hline Financial Account access (\% adults) & 1 & & \\
Private credit to GDP & 0.83 & 1 & \\
Branches per 100k km2 & 0.82 & 0.74 & 1 \\
\hline
\end{tabular}

Note: We run the cross-country correlations among inclusion, depth and development variables only in 2012, due to data availability restrictions. Financial inclusion survey (as provided by the Global Findex database) is available only for 1 year.

Table 8. Selected peer countries for the CEMAC countries

\begin{tabular}{|c|c|c|c|}
\hline CEMAC & Peer countries & $\begin{array}{l}\text { GDP per capita } \\
\text { constant } 2005 \text { us dollars }\end{array}$ & $\begin{array}{c}\text { Population } \\
\text { millions }\end{array}$ \\
\hline \multirow[t]{6}{*}{ Cameroon } & & 991.7 & 22.3 \\
\hline & Côte d'Ivoire & 1014.4 & 20.3 \\
\hline & Kenya & 606.2 & 44.4 \\
\hline & Zambia & 821.6 & 14.5 \\
\hline & Ghana & 766.1 & 25.9 \\
\hline & Mozambique & 435.7 & 25.8 \\
\hline \multirow[t]{5}{*}{ Central African Republic } & & 282.6 & 4.6 \\
\hline & Liberia & 299.4 & 4.3 \\
\hline & Eritrea & 196.6 & 6.3 \\
\hline & Togo & 424.4 & 6.8 \\
\hline & Sierra Leone & 513.2 & 6.1 \\
\hline \multirow[t]{5}{*}{ Chad } & & 741.6 & 12.8 \\
\hline & Rwanda & 388.0 & 11.8 \\
\hline & Senegal & 805.8 & 14.1 \\
\hline & Mali & 476.2 & 15.3 \\
\hline & Benin & 583.9 & 10.3 \\
\hline \multirow[t]{4}{*}{ Congo, Rep. } & & 1960.6 & 4.4 \\
\hline & Swaziland & 2429.7 & 1.2 \\
\hline & Lesotho & 978.3 & 2.1 \\
\hline & Namibia & 4581.7 & 2.3 \\
\hline \multirow[t]{4}{*}{ Equatorial Guinea } & & 10990.5 & 0.8 \\
\hline & Mauritius & 6679.2 & 1.3 \\
\hline & Botswana & 7028.1 & 2.0 \\
\hline & Seychelles & 14235.8 & 0.1 \\
\hline \multirow[t]{4}{*}{ Gabon } & & 6937.7 & 1.7 \\
\hline & Botswana & 7028.1 & 2.0 \\
\hline & Mauritius & 6679.2 & 1.3 \\
\hline & Namibia & 4581.7 & 2.3 \\
\hline
\end{tabular}

Sources: FinStats database; and our own calculations. 
Figure 6. Benchmarking financial development in selected CEMAC countries

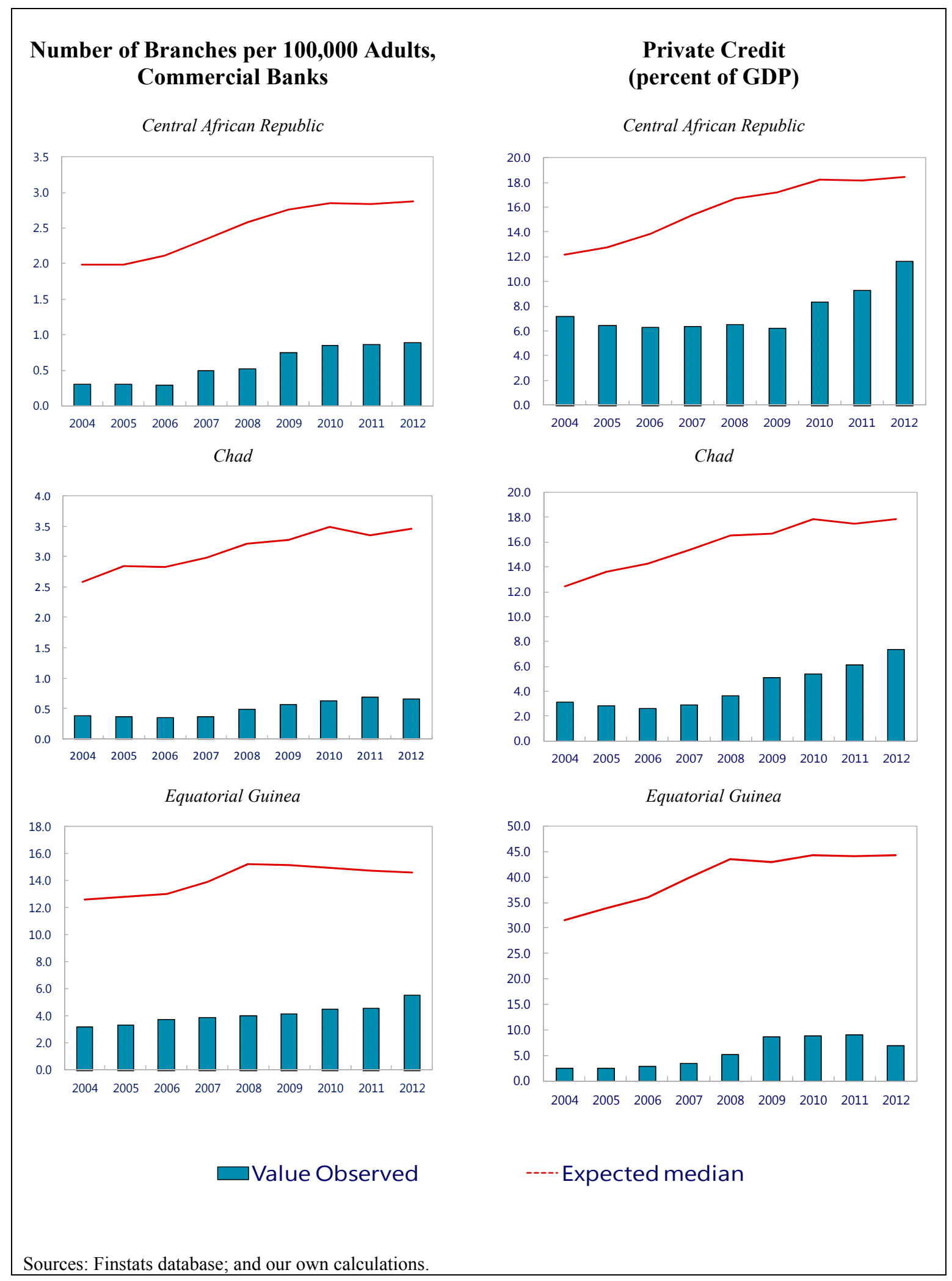




\section{TECHNICAL APPENDIX: BENCHMARKING FINANCIAL DEVELOPMENT}

This technical appendix follows the methodology based on Beck, et al. (2008) which has been extended in the manual of the FinStats database. As indicated in a canonical form by equation (A.1) of the three equation system, the financial development indicator $\mathrm{X}$ (at time t) can be written as a function of country's macroeconomic development characteristics (Y), policy variables $(\mathrm{P})$, structural characteristics $(\mathrm{Z})$ which are unrelated to policy, and finally, the error term $(\epsilon)$. The second equation (A.2) of this system shows that the macroeconomic characteristics (e.g., GDP per capita) depends on lagged policy and structural variables, reflecting the endogeneity feature of financial development on growth. The last equation (A.3) indicates the auto-regressive characteristic of policy innovations.

$X_{t}=\alpha Y_{t}+\beta P_{t}+\gamma Z_{t}+\epsilon_{t}$

$Y_{t}=\alpha^{\prime} P_{t-1}+\beta^{\prime} P_{t-1}+\gamma^{\prime} Z_{t}+\epsilon_{t}^{\prime}$

$P_{t}=\alpha " P_{t-1}+v_{t}$

Plugging equations A.2 and A.3 into equation A.1 delivers the reduced form regression of the financial development indicator $(X)$, which could be represented as a function of economic development (Y) and structural characteristics $(\mathrm{Z})$, while policy innovations would be incorporated into the error term.

Finally, the 2014 FinStats methodology estimates for each financial development indicator (X) the following regression (A.4) reflecting the above mentioned characteristics:

$$
\begin{aligned}
X_{i t}=\alpha+\beta_{1} & \log \left(\text { GDPperCapita }_{i t}\right)+\beta_{2} \log \left(\text { GDPperCapita }_{i t}\right)^{2} \\
& +\beta_{3} \log \left(\text { Poverty }_{i t}\right)+\beta_{4} \log \left(\text { PopulationSize }_{i t}\right) \\
& +\beta_{5}\left(\text { PopulationDensity }_{i t}\right)+\beta_{6}\left(\text { AgeDependencyYoung }_{i t}\right) \\
& +\beta_{7}\left(\text { AgeDependencyOld }_{i t}\right)+\beta_{8}\left({\text { DummyOff } \left.\text { Dhor }_{i t}\right)}\right) \\
& +\beta_{9}\left(\text { DummyTransition }_{i t}\right)+\beta_{10}\left(\text { DummyFuelExporter }_{i t}\right) \\
& +\beta_{11}\left(\text { Dummy }_{\text {Landlocked }}\right)+\gamma_{t}+\epsilon_{i t}
\end{aligned}
$$

The structural determinants of financial development indicator (X) for each country (i) and time $(\mathrm{t})$ are represented by economic development factors together with population and demographic characteristics, special circumstances (e.g., natural resources exporters, offshore financial centers, countries in transition or landlocked) and a global cycle. Equation A.4 is estimated using quantile regressions in order to reduce the impact of outliers. In this paper we utilize the median estimate for the benchmark of our financial development indicator (i.e., private credit to GDP). 